\title{
Utilization of phytoplankton in seston aggregates from the Elbe estuary, Germany, during early degradation processes
}

\author{
M. Kerner*, S. Yasseri \\ Institute of Hydrobiology and Fishery Science, University of Hamburg, Zeiseweg 9, D-22765 Hamburg, Germany
}

\begin{abstract}
A laboratory device was used to simulate the environmental conditions in a seston layer of about $1 \mathrm{~mm}$ thickness, similar to those in aggregates of the open water of the Elbe estuary, Germany. During $98 \mathrm{~h}$ of oxic, suboxic and anoxic incubation, microbial degradation was investigated by measuring both changes in the chemical composition of the particulate organic carbon (POC) and heterotrophic microbial activities. Mineralization of the POC at $15^{\circ} \mathrm{C}$ occurred at mean rates of 16 under oxic, 26 under suboxic, and $0.24 \mu \mathrm{mol} \mathrm{cm} \mathrm{cm}^{-3} \mathrm{~d}^{-1}$ under anoxic conditions. Different respiration processes accounted for ratios of carbon degradation equal to 1.7 for oxygen:nitrate, 430 for nitrate:manganese, and 3.5 for $\mathrm{Mn}(\mathrm{IV}) \mathrm{Fe}(\mathrm{III})$. During oxic and suboxic incubation, particulate combined amino acids (PCAA) were preferred as an organic substrate, and PCAA:C ratios decreased from about 0.12 to 0.02 . A total of $85 \%$ of the PCAA was degraded within $56 \mathrm{~h}$ including PCAA and dissolution of silica from the cell wall material of diatoms; the remaining amino acids were assumed to be those from active bacteria. Chlorophyll a (chla) was more resistant to degradation than total POC below a threshold value of $60 \mu \mathrm{M} \mathrm{O}_{2}$, which resulted in an increase of chl a:C ratios up to 37. A decrease in the availability of particulate substrates for heterotrophic decomposition was expressed as an accumulation of glycine and serine and a depletion in aspartic and glutamatic acid in the PCAA. During anoxic incubation PCAA decreased by only $18 \%$ and remained unchanged in composition. Along the longitudinal profile of the freshwater section of the Elbe estuary, gradual decomposition of the seston material during summer downstream transport was followed by changes in composition similar to those observed in the oxic laboratory experiments. The results indicate that phytoplankton debris that is not available as a substrate for microorganisms in sediments and small suspended particles is rapidly degraded within seston aggregates.
\end{abstract}

KEY WORDS: Microbial degradation - Respiration processes - Fermentation - Phytoplankton decay Seston aggregates - Availability of amino acids $\cdot$ Elbe estuary

\section{INTRODUCTION}

Understanding the microbial decomposition of particulate organic carbon (POC) in aquatic environments is important because it is a source of the energy, nutrients, and trace elements that control both primary and secondary production. Generally, processes and rates of microbial degradation depend on environmental conditions such as redox and temperature and the chemical composition of the organic matter. Redox

•E-mail:kerner@rrz.uni-hamburg.de conditions control the use of different inorganic and organic terminal electron acceptors, i.e. respiration and fermentation processes. Because the bacteria that perform these processes have different capacities to hydrolyze POC and differ in their substrate specificities towards the dissolved organic carbon (DOC) compounds (Ratledge 1994), the microbial availability of POC varies between the different mineralization processes. Apart from this autecological point of view, microbial interactions might significantly influence decomposition in habitats where the members of a diverse microbial community are physically close to each other. These habitats include aggregated parti- 
cles, sediment surfaces, biofilms and flocs of seston (Loosdrecht et al. 1990, Smith et al. 1992, Kepkay 1994, Kerner \& Gramm 1995)

The quantification of microbial processes within suspended particulate matter (SPM) is difficult because the environmental conditions within the particle are not always the same as in the surrounding water. In both freshwater and marine environments, SPM can be present in the form of aggregates from several $\mathrm{mm}$ to several $\mathrm{cm}$ in diameter, and steep redox gradients from oxic to anoxic conditions can occur within these aggregates (Jørgensen 1977, Alldredge \& Cohen 1987, Eisma 1993, Grossart \& Simon 1993). The redox layers allow different respiration processes to occur within the aggregates and, thus, degradations of different organic substrates may be closely associated within the space of a single aggregate (Sørensen et al. 1981, Lovley \& Phillips 1986). Furthermore, SPM is a mixture of organic matter of diverse biochemical structure and intrinsic stability. Thus, decomposition of SPM is insufficiently reflected by monitoring changes in the chemical properties that do not specifically characterize the bulk of the material.

Separation of SPM fractions using differences in their settling velocities has proven suitable for characterizing differences in the origin of the particles and their state of decomposition (Kerner \& Krogmann 1994). Chemical approaches to characterize the degradation processes focus on the determination of specific dissolved or particulate substances that are produced or consumed under defined environmental conditions (Lee 1992, Coffin et al. 1993, Hedges \& Keil 1995). Pigment compositions have been effectively used to determine both the phytoplankton community structure and the state of degradation of the phytoplankton in marine and freshwater systems (Furlong \& Carpenter 1988, Letelier et al. 1993, Head et al. 1994, Poryvkina et al. 1994). Recently, Kerner \& Edelkraut (1995) identified glycolaldehyde as an indicator of anaerobic degradation processes that occur in the open water of the Elbe estuary, Germany, in suspended seston aggregates $\geq 2 \mathrm{~mm}$ in diameter. Of the non-proteinaceous amino acids, $\beta$-alanine and $\gamma$ aminobutyric acid have been found to be diagenetic by-products during degradation of SPM. Both dissolved and particulate concentrations of these tend to increase as diagenesis progresses in sediments and in sedimenting particles, respectively, in the Amazon River (Cowie et al. 1992, Hedges et al. 1994). However, the formation of non-proteinaceous amino acids in particles does not always produce a predominance of these compounds, and their amounts relative to proteinaceous amino acids have been reported to remain constantly low on sinking particles in the Pacific (Lee \& Cronin 1982).
Here, we report an alternative approach which utilizes a defined particulate $\mathrm{C}$ pool within the complex mixture of organic molecules to estimate the state of decomposition of seston aggregates. Cell wall material of diatoms was used as the defined $C$ pool because it is known to contain glycine and serine (Hecky et al. 1973), and is relatively more resistant to degradation (Cowie et al. 1992). We hypothesize that during degradation of seston containing diatoms an increase in the proportion of glycine and serine relative to the other proteinaceous amino acids occurs, while the cell wall material remains undegraded. Generally, phytoplankton form an integral part of POC both in limnic and marine aggregates and are captured by particles through mechanisms of collision that include shear and differential settling (Grossart \& Simon 1993, Kiørboe \& Hansen 1993). In the Elbe estuary, Bacillariophyceae (diatoms) are the predominant phytoplankton components and account for up to $95 \%$ of the algal cells in sedimenting particles of diameter $>100 \mu \mathrm{m}$ (Dyer 1986 , Wolfstein \& Kies 1995). In this study, laboratory experiments were performed in which sedimenting seston from the Elbe estuary was incubated under defined oxic, suboxic and anoxic environmental conditions similar to the conditions in the Elbe during sampling, and changes in the biochemical composition of the particulate material were monitored. According to Froelich et al. (1979), environmental conditions are defined by the addition of inorganic terminal electron acceptors, which allow microbial oxygen reduction to be the predominant microbial process under oxic conditions, microbial nitrate reduction under suboxic conditions, and microbial $\mathrm{Mn}, \mathrm{Fe}$ and sulfate reduction under anoxic conditions. Results from the laboratory experiments were compared with studies along a longitudinal profile in the Elbe estuary during seasons of high and low microbial activity.

\section{MATERIAL AND METHODS}

Study site. The Elbe estuary has a length of about $142 \mathrm{~km}$, with the freshwater section (chlorinity $\sim 0.2 \%$ ) reaching from the weir at Geesthacht (km 590) to about Glückstadt ( $\mathrm{km}$ 670) (Fig. 1). The particulate organic carbon (POC) entering the estuary from upstream originates predominantly from riverine production as indicated by an average $\delta^{13} \mathrm{C}$ value of about $-28 \%$ (Kerner \& Krogmann 1994). Most of the POC is phytoplankton dominated by diatoms, which accounted for 90 and $71 \%$ of the total algal cell numbers in spring and summer, respectively, between 1989 and 1993 (Arge 1989-1993). Likewise, in March 1995, chlorophyll a (chl a):fucoxanthin ratios of between 2.2 and 2.8 were found at $\mathrm{km} 610$ of the Elbe estuary, indicative of 


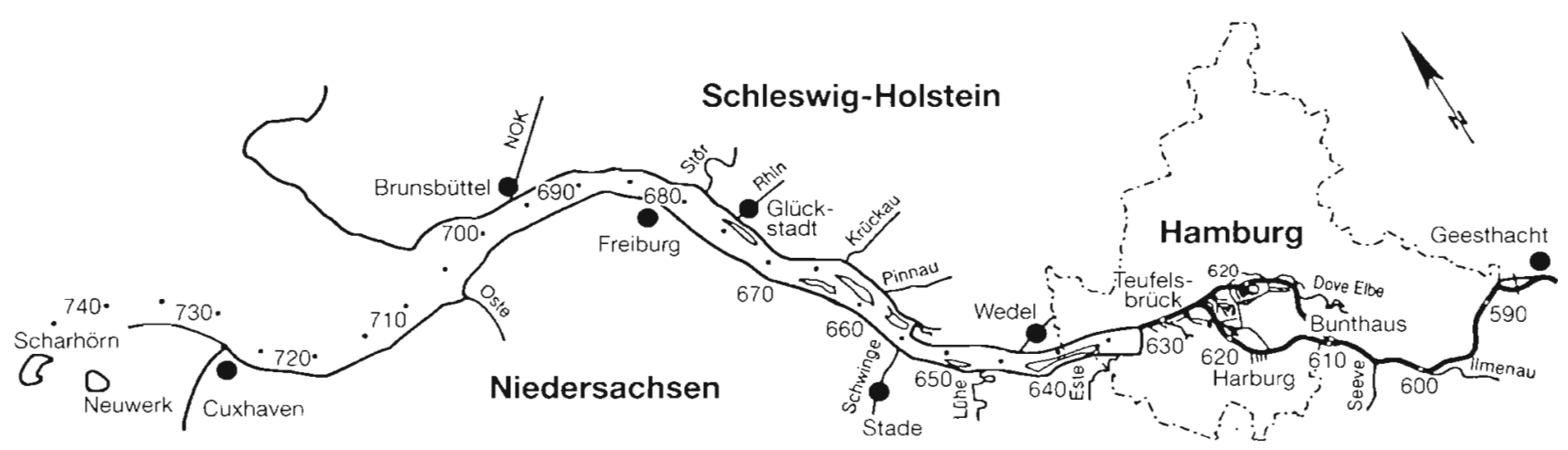

Fig. 1 The Elbe estuary, Germany, with the sampled freshwater section reaching from below the weir at Geesthacht (km 590) to about Glückstadt (km 670). Numbers are km markers

diatoms being the predominant phytoplankton present (F. Edelkraut pers. comm.).

During transport downstream the SPM passes through Hamburg harbour ( $\mathrm{km} \mathrm{625),} \mathrm{which} \mathrm{acts} \mathrm{as} \mathrm{a}$ sink for sedimenting particles. This not only affects the SPM from upstream but also the sedimenting particles, which are transported upstream during flood tide (Dyer 1988). Downstream from km 610 primary production is limited by light, and the increase in water depth to about $10 \mathrm{~m}$ and reduced vertical mixing might not allow even self-sustaining photosynthesis (Wofsy 1983, Wolfstein \& Kies 1995). Hence, along the longitudinal freshwater profile an increase in microbial degradation processes has been detected within the region downstream from Hamburg harbour due to the decay of phytoplankton (Kerner et al. 1995). This produces significant oxygen deficiencies in late spring when the water temperatures increase rapidly, reaching well above $15^{\circ} \mathrm{C}$ during summer, and the oxygen concentrations can fall below $95 \mu \mathrm{M} \mathrm{O}$. In winter, when temperatures remain $\leq 8^{\circ} \mathrm{C}$ and microbial activities are slowed, oxygen saturation persists in the same longitudinal profile.

Sampling. Field studies were started on 23 March 1993 and on 25 May 1993 and 31 May 1994 to observe the microbial activities during periods when winter and summer water temperatures prevailed. Water temperatures were about 8,19 , and $16^{\circ} \mathrm{C}$, respectively. During the 2-day cruises, 6 stations which slightly varled in position during the different campaigns were sampled in an upstream direction between $\mathrm{km} 674$ and 609 during water runoff (Fig. 1). At each station 20 l of water was taken from $2 \mathrm{~m}$ below the water surface at mid stream using a horizontally orientated sampler (Hydrobios, Kiel, Germany). For the laboratory studies in summer 1994 and 1995 (see Table 1), about 20 l of estuarine water were collected each time with a clean bucket from the water surface during ebb tide at Teufelsbrück ( $\mathrm{km}$ 630), downstream from Hamburg harbour (Fig. 1). During sampling for laboratory stud- ies, in situ temperature varied between 17.8 and $25.6^{\circ} \mathrm{C}$ and oxygen concentrations were between 113 and 212 $\mu \mathrm{M} \mathrm{O}_{2}$. In both laboratory and field studies, the SPM was fractionated and concentrated from the water samples by a sedimentation method described in detail by Kerner \& Krogmann (1994). A specially shaped funnel was used which allowed the separation of suspended particles capable of sedimentation at a rate of $\geq 0.02 \mathrm{~cm} \mathrm{~s}^{-1}$ (sed. PM) from the permanently suspended particles (susp. PM) of $\leq 0.1 \mathrm{~mm}$ diameter (Dyer 1986). Because most of the free-living zooplankton does not settle using this method, the sedimenting fraction was depleted of these, and degradation processes were restricted to the particle associated microbial community. Chemical analyses of dissolved and particulate substances were performed as described below. Additionally, microscopic studies including bacterial cell numbers and phytoplankton composition were performed during the field studies and results were published elsewhere (Böttcher et al. 1995, Schäfer \& Harms 1995, Wolfstein \& Kies 1995).

Only the sed. PM was used in the laboratory experiments to produce a seston layer in the incubation cell described below. While the experiments were being conducted, water samples were collected 3 times a day from the constantly mixed water columns overlying and underlying the seston layer. The particulate matter in 2 parallel batches was completely resuspended, removed and prepared for the determination of chemical composition after either 56 or $75 \mathrm{~h}$ and after 98 to 100 h of incubation (see Table 1).

Method of incubation. The laboratory device consisted of a round polycarbonate incubation cell (internal diameter $=40 \mathrm{~mm}$, internal height $=22 \mathrm{~mm}$ ) that was separated horizontally by an inflexible $\mathrm{Al}_{2} \mathrm{O}_{3}$ membrane (pore size $=0.2 \mu \mathrm{m}$, thickness $=60 \mu \mathrm{m}$ ) into 2 chambers, each $11 \mathrm{~mm}$ high, containing artificial Elbe water of known chemical composition. Before the start of the experiments, a seston layer was produced on top of the membrane using sed. PM obtained as 
described above. For 2 parallel incubations similar amounts of seston were allowed to settle in separate containers and sufficient material was used to produce similar, uniform depths of the layers in all experiments (see Table 1). The construction and function of the device has been described by Kerner \& Gramm (1995).

An incubation of the seston layer under defined environmental conditions similar to those for seston aggregates in the Elbe was allowed during the experiments by maintaining a constant $0.26 \mathrm{ml} \mathrm{min}^{-1}$ flow of artificial axenic Elbe water from two 15 I stock vessels through the chambers overlying and underlying the layer. The artificial Elbe water contained $5.6 \mathrm{mM} \mathrm{NaCl}$, $4.1 \mathrm{mM} \mathrm{MgSO}_{4}, 0.8 \mathrm{mM} \mathrm{CaSO}{ }_{4}, 81.6 \mu \mathrm{M} \mathrm{Na} 2 \mathrm{HPO}_{4}$, $51.7 \mu \mathrm{M} \quad \mathrm{KH}_{2} \mathrm{PO}_{4}, 0.21 \mathrm{mM} \quad \mathrm{NaNO}_{3}$ and $0.1 \mathrm{mM}$ ${ }^{15} \mathrm{NH}_{4} \mathrm{Cl}$. These concentrations are similar to those in natural Elbe water (Arge 1993). Chloride was added to the underlying chamber to produce a difference of $-8 \mathrm{mM} \mathrm{Cl}^{-}$with the overlying water, and the $\mathrm{pH}$ in both chambers was 7.1. Since $\mathrm{Cl}^{-}$concentrations reached in the chambers were within the bounds of the natural changes occurring in the Elbe estuary at the study sites, the effect on the physiological estimates was assumed to be negligible (Arge 1993). From the stable chloride concentrations reached during the experiments, the diffusion of chloride through the layer was calculated using Fick's first law assuming the diffusivity in the seston layer to be $88 \%$ of that in water (Sweerts et al. 1991). Thickness of the seston layer (see Table 1) was computed by equating the diffusion to the mass transport of chloride from the respective chambers of the incubation cell (Kerner \& Gramm 1995). Oxic microbial respiration processes were initiated in the layer by the addition of oxygen as a terminal electron acceptor. For that, the artificial water flowing into the upper chamber was kept at a constant $116 \mu \mathrm{M} \mathrm{O}_{2}$ by aeration with an appropiate $\mathrm{N}_{2} / \mathrm{O}_{2}$ gas mixture (MKS, Multigas Controller 147) to simulate Elbe water. Water in the chamber underlying the seston layer was deoxygenated by constant bubbling with $\mathrm{N}_{2}$ to simulate anaerobic pore water. To simulate suboxic conditions, anaerobic water was used in both chambers with nitrate and sulfate added as the terminal electron acceptor at amounts listed above. Anoxic conditions in both chambers were simulated using anaerobic water with no nitrate, but with added sulfate. Respiration processes were then possible only by using sulfate and the particulate Fe(III) and Mn(IV), which accounted for about 3 and $0.5 \%$ of the seston material, respectively (Kerner \& Krogmann 1994). All experiments were conducted at $15^{\circ} \mathrm{C}$ in the dark with an argon atmosphere to eliminate any intrusion of $\mathrm{O}_{2}$

Analytical procedures. The precision of all measurements was better than $\pm 5 \%$, unless otherwise stated. $\mathrm{Cl}^{-}, \mathrm{NO}_{3}^{-}, \mathrm{NO}_{2}^{-}$and $\mathrm{NH}_{4}^{+}$were analyzed in filtered
(Minisart, pore size $=0.45 \mu \mathrm{m}$ ) water samples using flow injection analysis (Tecator. Aquatec 5020, Germany) by the method of Grasshoff et al. (1983). Samples had been stored at $-20^{\circ} \mathrm{C}$ for less than $1 \mathrm{wk}$. The detection limit was $0.14 \mathrm{mM}$ for chloride, $0.07 \mu \mathrm{M}$ for nitrite, $2 \mu \mathrm{M}$ for nitrate and $0.7 \mu \mathrm{M}$ for ammonium.

Oxygen, $\mathrm{pH}$ and $\mathrm{CO}_{2}$ during the laboratory experiments were measured directly at the chamber outlets using a glass flow-through cell containing specific electrodes (Eschweiler and Co., Kiel, Germany). The detection limit for oxygen was $0.3 \mu \mathrm{M}$. The detection limit for dissolved $\mathrm{CO}_{2}$ at the given $\mathrm{pH}$ of 7.1 was $0.02 \mathrm{mM}$. The sum of $\mathrm{CO}_{2}$ in all dissolved ionic forms was calculated from the $\mathrm{pH}$ and ionic strength. In the field studies, $\mathrm{O}_{2}$ concentrations in the Elbe water were determined at the sampling sites with an $\mathrm{O}_{2}$-sensitive probe (WTW, Oxi-Digi 91, Germany).

Extracellular proteolytic enzyme activity (EEA) was determined in samples from field and laboratory experiments by hydrolysis of fluorogenic L-leucine4-methylcoumarinyl-7-amide $\mathrm{HCl}$ (Leu-MCA, Sigma Chemie, Germany) added to a concentration of $5 \mu \mathrm{M}$ to ensure saturation kinetics (Hoppe 1983). At the beginning and after $1 \mathrm{~h}$ of incubation at room temperature in the dark, the concentration of MCA was determined using a spectrofluorometer at excitation and emission wavelengths of 365 and $455 \mathrm{~nm}$, respectively. Activities are shown for the particulate matter present.

Particulate organic carbon (POC) and particulate nitrogen (PN) in the particulate subsamples were determined with an Elemental Analyser, Model 1108 (Carlo-Erba, Italy). Samples prepared by filtration on pre-ashed $\left(450^{\circ} \mathrm{C}\right)$ and pre-weighed Anopore $\mathrm{Al}_{2} \mathrm{O}_{3}$ filters (pore size $=0.2 \mu \mathrm{m}$ ) were dried at $70^{\circ} \mathrm{C}$. Inorganic carbonates were removed by fuming the filters with concentrated $\mathrm{HCl}$ for $2 \mathrm{~min}$. The detection limit of both $\mathrm{N}$ and $\mathrm{C}$ was below $0.4 \mu \mathrm{mol}$, and $\mathrm{C}: \mathrm{N}$ ratios were calculated from the molar concentrations. Mass values of POC were used to compute chl a:C and particulate combined amino acids (PCAA): $\mathrm{C}$ ratios. Exchangeable ammonium was determined in $2 \mathrm{M} \mathrm{KCl}$ extracts of the particulate matter and is given as the percentage of $\mathrm{PN}$ (see Table 1). We define exchangeable $\mathrm{NH}_{4}^{+}$as adsorbed $\mathrm{NH}_{4}{ }^{+}$, which includes ammonium on the surface of clay minerals and ammonium associated with organic matter (Rosenfeld 1979).

The amount of biogenic opal in the particulate matter was determined by refluxing 5 to $10 \mathrm{mg}$ dry wt with 10 $\mathrm{ml}$ of $0.1 \mathrm{~N} \mathrm{NaOH}$ solution at $85^{\circ} \mathrm{C}$ for $5 \mathrm{~h}$. During the reflux, $1 \mathrm{ml}$ subsamples were taken every hour and analyzed for $\mathrm{SiO}_{2}$ by a photometric method using an Anthos htII microplate reader (Grasshoff et al. 1983). The deviation of the regression line calculated from the concentrations at the different times of extraction gives the amount of biogenic opal (Demaster 1981). 
PCAA in the particulate matter from both laboratory and field studies were determined using a reverse phase HPLC coupled to a fluorescence detector after ophthaldialdehyde precolumn derivatization of the hydrolyzed samples (Mopper \& Lindroth 1982). Prior to analysis, samples that had been dried in a vacuum and stored at $-20^{\circ} \mathrm{C}$ were hydrolyzed with $6 \mathrm{~N} \mathrm{HCl}$ at $110^{\circ} \mathrm{C}$ for $22 \mathrm{~h}$ in an argon atmosphere with ascorbic acid added to prevent amino acid oxidation. The hydrolysates were evaporated to dryness in vacuum and taken up in borate buffer. Additionally, total dissolved amino acids (DAA) were determined in the laboratory studies in $0.2 \mu \mathrm{m}$ filtrates from the chambers underlying the seston layer hydrolyzed as described for PCAA. Dissolved free amino acids (DFAA) were determined in non-hydrolyzed filtrates and dissolved combined amino acids (DCAA) were calculated by subtracting DFAA from DAA.

The precision of the preparation and analysis was \pm 3 to $5 \%$ for most of the amino acids, but it was $\pm 15 \%$ for lysine and aspartic acid. Using the method described above, all 20 ubiquitous proteinaceous amino acids were detected. Due to the large variations in natural bacterioplankton and phytoplankton it is impossible to assign proteinaceous material to the biomass of one of these groups on the basis of the amino acid composition (Cowie \& Hedges 1992).

Phytoplankton biomass was determined from the pigments chl a and fucoxanthin, the latter indicative of diatoms (Richter 1988). For the analyses, acetone was immediately added to samples on GF/F Whatman filters and stored in the dark at $-20^{\circ} \mathrm{C}$ for less than a week. Prior to analysis, the filters were homogenized by ultrasonification. Separation of pigments in the acetone filtrate was accomplished using an isocratic HPLC method (Daemen 1986), and concentrations were determined by absorbance at $436 \mathrm{~nm}$. Calibration of chl a was conducted using Sigma external standards, while ratios of chl a:fucoxanthin were calculated on the basis of the peak areas, because no fucoxanthin standard was available.

Concentrations of sulfide, Fe(II) and Mn(II) were determined in $5 \mathrm{ml}$ of unfiltered water according to Luther et al. (1985) by differential pulse polarography using a 647 VA polarograph and 646 VA processor (Metrohm, Switzerland) with a static Hg electrode. The sample was taken by directing the outlet of the incubation cell into a Hamilton gas-tight syringe. The detection limit was $0.03 \mu \mathrm{M}$ for total $\mathrm{H}_{2} \mathrm{~S}$ and $0.9 \mu \mathrm{M}$ for Fe(II) and Mn(II).

${ }^{15} \mathrm{~N}$-ammonium (98 atom\%; Amersham) was added as a tracer to artificial Elbe water in the laboratory experiments as described above. In subsamples of the water analyzed for inorganic $\mathrm{N}$ species by colorimetric analysis, $\mathrm{NH}_{4}^{+}$was eliminated by purging with $\mathrm{N}_{2}$ after raising the $\mathrm{pH}$ to 9.2 with borate buffer. The emerging gas was trapped in $3 \mathrm{ml}$ of $0.04 \mathrm{~N} \mathrm{H}_{2} \mathrm{SO}_{4}$. The 2 fractions containing $\mathrm{NO}_{3}{ }^{-}+\mathrm{NO}_{2}{ }^{-}$or $\mathrm{NH}_{4}{ }^{+}$were analyzed for ${ }^{15} \mathrm{~N}$ and ${ }^{14} \mathrm{~N}$ with emission spectroscopy (Jasco Model $N$ 151) after transformation of the nitrogen species to $\mathrm{N}_{2}$ at $10^{-4}$ torr by the Dumas method. Nitrification rate was calculated from the dilution of $\mathrm{NO}_{3}{ }^{-}+\mathrm{NO}_{2}{ }^{-}$with ${ }^{15} \mathrm{~N}-\mathrm{NH}_{4}{ }^{+}$according to the Blackburn-Caperon model (Laws 1984). ${ }^{15} \mathrm{~N}$-PON (particulate organic ${ }^{15} \mathrm{~N}$ ) was calculated from ${ }^{15} \mathrm{~N}$-PN determined in the seston obtained at the end of the incubation by subtraction of the ${ }^{15} \mathrm{~N}$-extractable ammonium. ${ }^{15} \mathrm{~N}$-PON was assumed to be produced from assimilated ${ }^{15} \mathrm{~N}-\mathrm{NH}_{4}{ }^{+}$, and the production of microbial biomass was computed using the equations derived by Dugdale \& Goering (1967).

Mineralization of the organic carbon was calculated from the respiration of the inorganic terminal electron acceptors using the stoichiometric reactions

$$
\begin{aligned}
& \mathrm{O}_{2}+4 \mathrm{e}^{-}+4 \mathrm{H}^{+} \rightarrow 2 \mathrm{H}_{2} \mathrm{O} \\
& \mathrm{NO}_{3}^{-}+5 \mathrm{e}^{-}+6 \mathrm{H}^{+} \rightarrow 1 / 2 \mathrm{~N}_{2}+3 \mathrm{H}_{2} \mathrm{O} \\
& \mathrm{NO}_{3}^{-}+2 \mathrm{e}^{-}+2 \mathrm{H}^{+} \rightarrow \mathrm{NO}_{2}^{-}+\mathrm{H}_{2} \mathrm{O} \\
& \mathrm{MnO}_{2}+2 \mathrm{e}^{-}+4 \mathrm{H}^{+} \rightarrow \mathrm{Mn}^{2+}+2 \mathrm{H}_{2} \mathrm{O} \\
& \mathrm{FeOOH}+\mathrm{e}^{-}+3 \mathrm{H}^{+} \rightarrow \mathrm{Fe}^{2+}+2 \mathrm{H}_{2} \mathrm{O}
\end{aligned}
$$

Because 4 electrons are transferred during oxidation of organic $\mathrm{C}$ to $\mathrm{CO}_{2}$, for each $\mathrm{CO}_{2}, 1 \mathrm{O}_{2}$ is consumed as the terminal electron acceptor determined as the total oxygen consumption - (nitrification $\times 2$ ). For other terminal electron acceptors the ratios to $\mathrm{CO}_{2}$ are $1: 1.25$ or 1:0.5 for $\mathrm{NO}_{3}^{-}, 1: 0.5$ for $\mathrm{Mn}^{4+}$ and 1:0.25 for $\mathrm{Fe}^{3+}$. Equal results for calculated and measured $\mathrm{CO}_{2}$ production indicated that oxidation of organic matter was coupled only to respiration processes, and that all carbon used was mineralized. $\mathrm{CO}_{2}$ evolution that exceeded production calculated from respiration $>2 \times$ indicated that additional $\mathrm{CO}_{2}$ must have been produced in fermentation processes (Kerner 1993).

\section{RESULTS}

\section{Laboratory studies}

\section{Mineralization processes}

Mineralization rates in parallel incubations $(\mathrm{A} / \mathrm{B}$, $\mathrm{C} / \mathrm{D}, \mathrm{E} / \mathrm{F}, \mathrm{G} / \mathrm{H}$ ) calculated from the consumption of inorganic terminal electron acceptors differed by less than $10 \%$, and confirmed the reproducibility of the experiments. Both oxic and suboxic respiration processes resulted in complete mineralization of the organic matter used during the incubations as a substrate, and the production of $\sum \mathrm{CO}_{2}$ (total $\mathrm{CO}_{2}$ ) accounted in most instances for at least $90 \%$ of the total electron 
transfers. Mineralization, however, resulted in a release of ammonium only under suboxic conditions. During oxic incubation, nitrification and $\mathrm{NH}_{4}{ }^{+}$assimilation exceeded production of $\mathrm{NH}_{4}{ }^{+}$, and net consumption continuously increased during the experiment.

Aerobic conditions always occurred within the -1 mm layer, with mean concentrations of oxygen during oxic incubation in July 1995 in the water overlying and underlying the layer of 56 and $17 \mu \mathrm{M} \mathrm{O}_{2}$, respectively. At these oxygen concentrations, the mean total degradation rate was $16 \mu \mathrm{mol} \mathrm{C} \mathrm{cm}^{-3} \mathrm{~d}^{-1}$. Aerobic denitrification increased with time and after $4 \mathrm{~d}$ of oxic incubation accounted for about half of the total degradation (Fig. 2a). This increase in denitrification was not explained by changes in the redox potential because it was independent of changes in total oxygen consumption produced in mineralization and nitrification processes (Fig. 2a). Nitrification in the seston layer always accounted for less than $29 \%$ of the total oxygen consumption. Similar rates were obtained during July 1994, when the layer was $\sim 1.5 \mathrm{~mm}$ and respective oxygen concentrations were 31 and $6 \mu \mathrm{M} \mathrm{O}_{2}$. Under these conditions, mineralization processes calculated from the consumption of terminal electron acceptors differed by less than $20 \%$ from those observed during July 1995.

During the suboxic incubation, nitrate was the dominant terminal electron acceptor throughout, with manganese reduction accounting for only $0.23 \%$ of the total $C$ degradation, the mean rate of which was $26 \mu \mathrm{mol} \mathrm{C} \mathrm{cm} \mathrm{Cm}^{-3} \mathrm{~d}^{-1}$ (Fig. 2b). Incomplete reduction of nitrate to nitrite occurred only when denitrification increased significantly during Days 1 and 2 of suboxic incubation, and $\mathrm{NO}_{2}{ }^{-}$accumulated to concentrations up to $64 \mu \mathrm{M}$.

During the anoxic incubation, the mean degradation rate calculated from $\mathrm{Mn}$ (IV) and Fe(III) reduction was $0.24 \mu \mathrm{mol} \mathrm{C} \mathrm{cm} \mathrm{cm}^{-3} \mathrm{~d}^{-1}$ and was thus below that of oxic and suboxic degradation by a factor of about 50 (Fig. 2c). A decrease in both $M n(I V)$ and Fe(III) reduction occurred during the whole experiment, with the ratio of $\mathrm{Mn}(\mathrm{IV})$ : $F e(I I I)$ reduction constant at about 3.5 . The net release of ammonium during the first $2 \mathrm{~d}$ of the experiment exceeded any possible production calculated from the $\mathrm{Mn}(\mathrm{IV})$ and Fe(III) respiration. From the production of $\Sigma \mathrm{CO}_{2}$, which reached $11 \mu \mathrm{mol} \mathrm{cm}^{-3}$ $\mathrm{d}^{-1}$ only during Days 1 and 2 of the experiment, it was concluded that additional mineralization processes must have occurred initially. Sulfate reduction could not be detected from the sulfide concentrations, which remained below those expected from equilibrium calculations based on the sulfidic minerals present. Fermentation processes, however, would explain the observed releases of both $\Sigma \mathrm{CO}_{2}$ and ammonium during the first $2 \mathrm{~d}$ of the experiment.
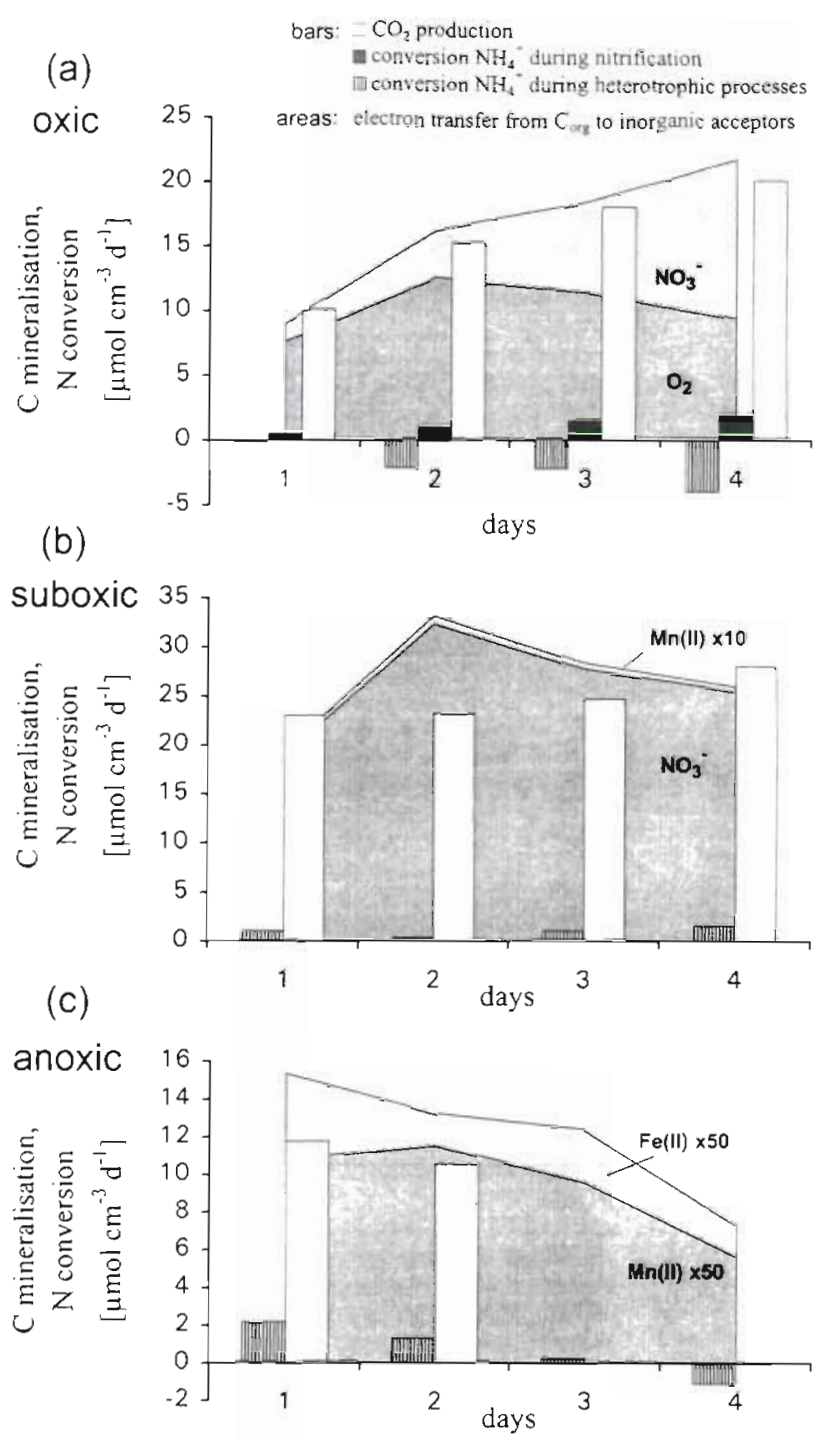

Fig. 2. Laboratory studies. Time course of degradation of organic matter $\left(\mathrm{C}_{\text {org }}\right)$ calculated from the electron transfer during the respiration processes (shaded areas) within a layer of aggregated seston from the Elbe estuary during (a) oxic, (b) suboxic and (c) anoxic incubations in July 1995. August 1994 and September 1994, respectively. Time course of production of $\mathrm{CO}_{2}$ during mineralization and the ammonium conversion during nitrification and heterotrophic processes (bars) are included for comparison. Notice that the data for Fe and $\mathrm{Mn}$ were multiplied by a factor of 10 (in b) and 50 (in c) to allow easier comparison between the different respiration processes

\section{Decomposition and production of biomass}

The changes in the biochemical composition of the seston layer during microbial decomposition processes are shown in Table 1 The POC content of the sed. PM was only about $1 / 3$ of that in the susp. PM and indicated high amounts of inorganic matter. The POC in the sed. PM was mainly phytoplankton, which were dominated 
Table 1 SPM (suspended particulate matter) from the Elbe estuary fractionated into sedimenting (sed. PM) and permanently suspended (susp. PM) matter and changes in composition of sed. PM during different times after formation of a seston layer in parallel batches $(A / B, D / C, E / F, G / H)$ under defined redox conditions. Values in bold indicate changes of $\leq 10 \%$, which are assumed to be not significant because they might have been produced by differences in the parallel batches

\begin{tabular}{|c|c|c|c|c|c|c|c|c|c|c|c|c|c|}
\hline $\begin{array}{r}\text { Experimental } \\
\text { Date of } \\
\text { Hou }\end{array}$ & $\begin{array}{l}\text { condition: } \\
\text { sampling: } \\
\text { Irs (batch): }\end{array}$ & 0 (Elbe) & $\begin{array}{l}\text { Oxic } \\
8 \mathrm{Jul} 10 \\
75(\mathrm{~A})\end{array}$ & 994 & $\begin{array}{c}1 \\
\text { O(Elbe) }\end{array}$ & $\begin{array}{l}\text { Suboxic } \\
\text { Aug } 19 \\
56(D)\end{array}$ & $\begin{array}{l}\text { C } \\
104(\mathrm{C})\end{array}$ & o(Elbe) & $\begin{array}{l}\text { Anoxic } \\
\text { Sep } 199 \\
76(E)\end{array}$ & $99(F)$ & $\begin{array}{r}3 \mathrm{~J} \\
0 \text { (Elbe) }\end{array}$ & $\begin{array}{l}\text { Oxic } \\
\text { ul } 1995 \\
\text { ) } 56(G)\end{array}$ & $98(\mathrm{H})$ \\
\hline Seston layer thickness ( $\mathrm{mm}$ ) & & & 1.56 & 1.86 & & 1.20 & 1.22 & & 1.90 & 1.85 & & 1.00 & 1.10 \\
\hline $\begin{array}{l}\text { Dry weight } \\
\text { (mg l } \\
\left(\mathrm{mg} \mathrm{l^{-1 }}\right) \\
(\mathrm{mg})\end{array}$ & $\begin{array}{l}\text { Susp. PM } \\
\text { Sed. PM } \\
\text { Sed. PM }\end{array}$ & $\begin{array}{l}13 \\
9.7 \\
64\end{array}$ & 48 & 46 & $\begin{array}{l}13 \\
8.7 \\
74\end{array}$ & 53 & 50 & $\begin{array}{c}12 \\
11 \\
110\end{array}$ & 90 & 81 & $\begin{array}{c}11 \\
10 \\
114\end{array}$ & 99 & 88 \\
\hline $\begin{array}{l}\text { Chl a } \\
\left.(\mu g]^{-1}\right) \\
\left(\mu g 1^{-1}\right) \\
(\mu g)\end{array}$ & $\begin{array}{l}\text { Susp. PM } \\
\text { Sed. PM } \\
\text { Sed. PM }\end{array}$ & $\begin{array}{c}63 \\
21 \\
136\end{array}$ & 120 & 101 & $\begin{array}{l}54 \\
20 \\
178\end{array}$ & 133 & 111 & $\begin{array}{c}15 \\
15 \\
152\end{array}$ & 121 & 85 & $\begin{array}{c}11 \\
17 \\
184\end{array}$ & 106 & 97 \\
\hline Chl a:fucoxanthin & $\begin{array}{l}\text { Susp. PM } \\
\text { Sed. PM }\end{array}$ & $\begin{array}{l}1.8 \\
1.4\end{array}$ & 1.5 & 1.2 & $\begin{array}{l}3.0 \\
2.2\end{array}$ & 1.8 & 2.1 & $\begin{array}{l}2.0 \\
1.3\end{array}$ & 1.5 & 1.5 & $\begin{array}{l}2.6 \\
1.4\end{array}$ & 0.9 & 1.3 \\
\hline $\begin{array}{l}\text { Chl a:C } \\
\quad\left(\mu \mathrm{gg}^{-1}\right)\end{array}$ & Sed. PM & 26 & 34 & 37 & 29 & 30 & 36 & 16 & 17 & 13 & 19 & 14 & 17 \\
\hline $\begin{array}{l}\text { C } \\
\left(\mu g \mathrm{mg}^{-1}\right) \\
\left(\mu \mathrm{g} \mathrm{mg}^{-1}\right)\end{array}$ & $\begin{array}{l}\text { Susp. PM } \\
\text { Sed. PM }\end{array}$ & $\begin{array}{c}231 \\
83\end{array}$ & 72 & 59 & $\begin{array}{l}247 \\
82\end{array}$ & 83 & 62 & $\begin{array}{l}338 \\
87\end{array}$ & 81 & 78 & $\begin{array}{c}264 \\
86\end{array}$ & 76 & 64 \\
\hline $\begin{array}{l}N \\
\left(\mu \mathrm{g} \mathrm{mg}^{-1}\right) \\
\left(\mu \mathrm{g} \mathrm{mg}^{-1}\right)\end{array}$ & $\begin{array}{l}\text { Susp. PM } \\
\text { Sed. PM }\end{array}$ & $\begin{array}{l}29 \\
11\end{array}$ & 8.7 & 7.3 & $\begin{array}{l}33 \\
12\end{array}$ & 8.9 & 6.2 & $\begin{array}{l}39 \\
12\end{array}$ & 9.9 & 9.4 & $\begin{array}{l}48 \\
13\end{array}$ & 11 & 9.7 \\
\hline Adsorbed $\mathrm{NH}_{4}{ }^{+}$of $\mathrm{N}(\%)$ & Sed. PM & 4.6 & 4.1 & 3.9 & 5.3 & 1.9 & 2.2 & 1.7 & 1.7 & 1.2 & 2.3 & 0.1 & 0.1 \\
\hline$C: N$ & $\begin{array}{l}\text { Susp. PM } \\
\text { Sed. PM }\end{array}$ & $\begin{array}{l}9.3 \\
9.1\end{array}$ & 9.7 & 9.4 & $\begin{array}{l}8.7 \\
8.3\end{array}$ & 10.8 & 11.7 & $\begin{array}{r}10.1 \\
8.7\end{array}$ & 9.5 & 9.7 & $\begin{array}{l}6.4 \\
7.8\end{array}$ & 8.1 & 7.7 \\
\hline $\begin{array}{l}\text { Biogenic opal } \\
\text { ( } \mu \mathrm{mg}^{-1} \text { dry wt) }\end{array}$ & Sed. PM & 46.6 & 10.3 & 28.4 & 46.8 & 27.3 & 30.8 & 40.0 & 34.3 & 43.6 & 90.9 & 54.3 & 52.9 \\
\hline Assimilated ${ }^{15} \mathrm{NH}_{4}{ }^{+}$of $\mathrm{N}(\%)$ & Sed. PM & & 4.0 & 6.3 & & 3.9 & 4.4 & & 1.6 & 2.1 & & 4.3 & 4.8 \\
\hline $\begin{array}{l}\text { Particulate combined amino } \\
\left(\mu \mathrm{mol} \mathrm{mg}^{-1} \text { dry wt }\right) \\
\left(\mu \mathrm{mol} \mathrm{mg}^{-1} \text { dry wt }\right)\end{array}$ & $\begin{array}{l}\text { acids (PCA } \\
\text { Susp. PM } \\
\text { Sed. PM }\end{array}$ & $\begin{array}{l}1.17 \\
0.163\end{array}$ & 0.033 & 0.029 & $\begin{array}{c}1.05 \\
0.183\end{array}$ & 0.029 & 0.044 & $\begin{array}{l}0.91 \\
0.193\end{array}$ & 0.159 & 0.157 & $\begin{array}{l}1.07 \\
0.168\end{array}$ & 0.018 & 0.016 \\
\hline $\begin{array}{l}\text { PCAA-C:C } \\
\left(\mu \mathrm{g} \mu \mathrm{g}^{-1}\right) \\
\left(\mu \mathrm{g} \mu \mathrm{g}^{-1}\right)\end{array}$ & $\begin{array}{l}\text { Susp. PM } \\
\text { Sed. PM }\end{array}$ & $\begin{array}{l}0.262 \\
0.110\end{array}$ & 0.026 & 0.027 & $\begin{array}{l}0.228 \\
0.123\end{array}$ & 0.019 & 0.039 & $\begin{array}{l}0.113 \\
0.117\end{array}$ & 0.103 & 0.105 & $\begin{array}{l}0.203 \\
0.110\end{array}$ & 0.013 & 0.014 \\
\hline $\begin{array}{r}\text { PCAA-N:N } \\
\left(\mu g \mu g^{-1}\right) \\
\left(\mu g \mu g^{-1}\right)\end{array}$ & $\begin{array}{l}\text { Susp. PM } \\
\text { Sed. PM }\end{array}$ & $\begin{array}{l}0.692 \\
0.268\end{array}$ & 0.068 & 0.071 & $\begin{array}{l}0.528 \\
0.271\end{array}$ & 0.057 & 0.125 & $\begin{array}{l}0.393 \\
0.282\end{array}$ & 0.281 & 0.290 & $\begin{array}{l}0.383 \\
0.242\end{array}$ & 0.029 & 0.030 \\
\hline $\begin{array}{l}\text { Extraceilular proteolytic enz } \\
\left.\left(\mu \mathrm{mol} \text { leu-MCA d }{ }^{-1}\right]^{-1}\right) \\
\left(\mu \mathrm{mol} \text { leu-MCA d }{ }^{-1} \mathrm{l}^{-1}\right)\end{array}$ & $\begin{array}{l}\text { Susp. PM } \\
\text { Sed. PM }\end{array}$ & $\begin{array}{l}\text { vity at } 25 \\
0.32 \\
0.087\end{array}$ & $3^{\circ} \mathrm{C} / \mathrm{EE}$ & & $\begin{array}{l}0.42 \\
0.065\end{array}$ & & & $\begin{array}{l}0.32 \\
0.056\end{array}$ & & & $\begin{array}{l}0.69 \\
0.083\end{array}$ & & \\
\hline $\begin{array}{l}\text { (nmol leu-MCA } \\
d^{-1} \mathrm{mg}^{-1} \text { dry wt) }\end{array}$ & Sed. PM & 8.3 & 1.5 & 0.7 & 6.7 & 0.5 & 0.4 & 4.7 & 1.2 & 1.1 & 6.9 & 0.9 & 0.9 \\
\hline
\end{tabular}

by diatoms, as indicated by chl a:C ratios mostly above 16 and chl a:fucoxanthin ratios below 2.2. Concentrations of PCAA were initially similar in the seston used in all 4 experiments and accounted for about $12 \%$ of POC. The PCAA composition was characterized by a preponderance of glycine and serine and a scarcity of aspartic and glutamatic acid while the other proteinaceous amino acids were mostly within the range found for living phytoplankton (Fig. 3). At the end of 75 and 56 h of continuous oxic and suboxic incubation, respectively, 76 to $88 \%$ of the PCAA was decomposed (Table 1) and the PCAA composition of the seston had changed to become more similar to that of living phytoplankton (Fig. 3a, b).
Coupled with this was a decrease in biogenic opal of about $50 \%$ which must have been produced only by the dissolution of silica from the frustules of the cell wall of diatoms, because other biogenic sources can be excluded in the Elbe estuary. During further oxic and suboxic incubation lasting about $98 \mathrm{~h}$, little decrease in PCAA concentrations occurred (Table 1) and PCAA composition remained unchanged (Fig. 3a, b). Even during selective use of PCAA as a substrate there was not always an increase in the $\mathrm{C}: \mathrm{N}$ ratio, indicating that the PN lost during degradation was counterbalanced by incorporation of $\mathrm{N}$ into the microbial biomass. A marked increase in the C: $\mathrm{N}$ ratio occurred only during suboxic 

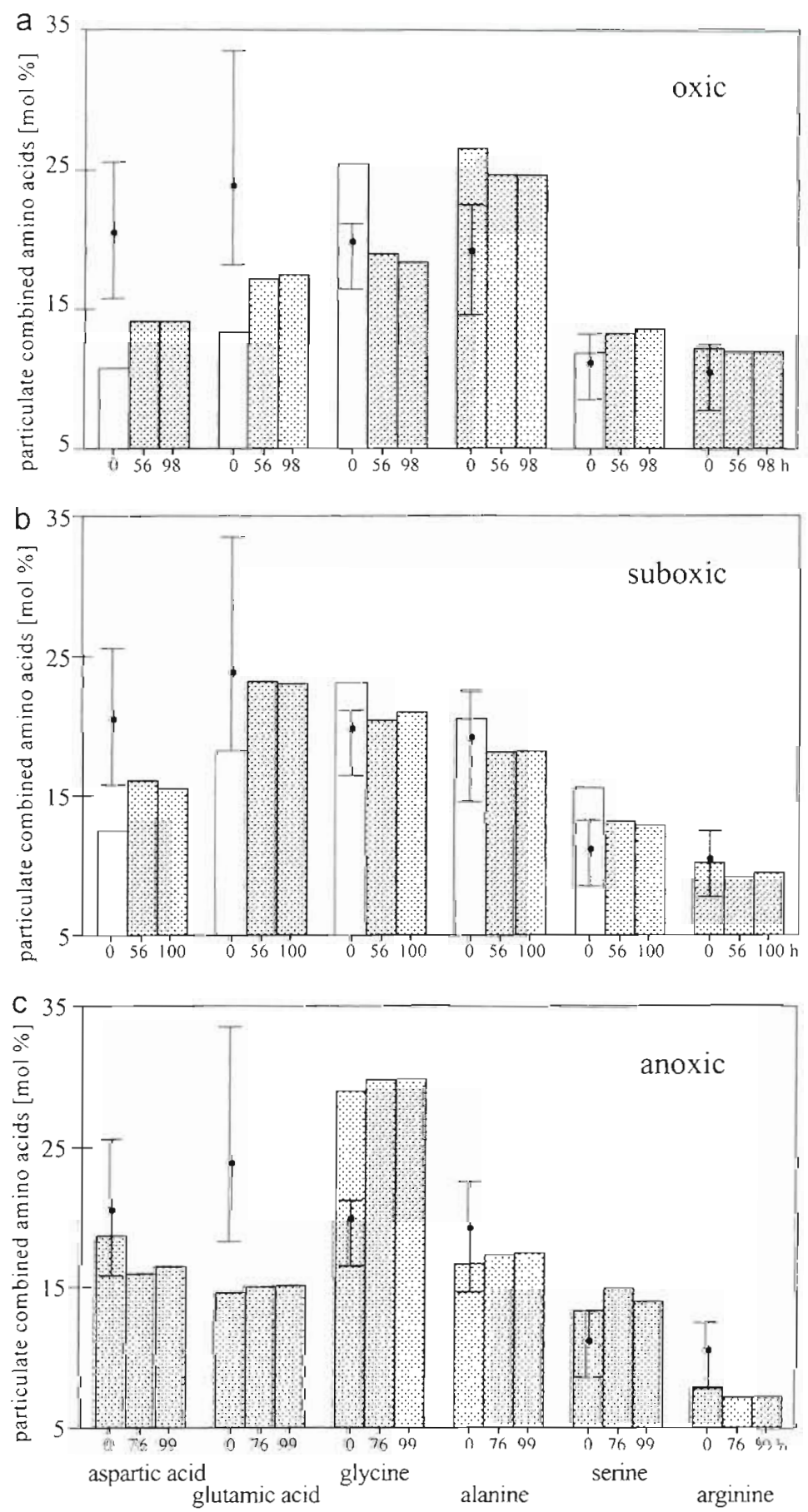

Fig. 3. Laboratory studies. Relative abundances in molar percentages of individual amino acids in a layer of aggregated seston from the Elbe estuary during (a) oxic, (b) suboxic and (c) anoxic degradation in July 1995. August 1994 and September 1994, respectively. Shaded bars indicate that differences in the proportions do not exceed analytical precision. For comparison, proportions in phytoplankton (point: mean; error bars: ranges) reported by Cowie \& Hedges (1992) are included

incubation and was coupled to a decrease in adsorbed ammonium that accounted for $13 \%$ of the decrease in PN (Table 1). During anoxic incubation, $82 \%$ of the
PCAA in the seston remained resistant to degradation, and mostly no significant changes were observed in the PCAA composition (Fig. 3c), the C:N ratio, the extractable $N$ and the concentrations of POC and biogenic opal (Table 1).

Calculated production of biomass from the uptake of ${ }^{15} \mathrm{~N}$-ammonium accounted for about $5 \%$ of the PN after about $98 \mathrm{~h}$ of both oxic and suboxic incubation, while during anoxic conditions the respective value was only $2 \%$ (Table 1). Because photosynthesis was absent and the rates of respiration utilizing nitrate under oxic conditions were high, ammonium was assimilated in our experiments nearly exclusively by heterotrophic bacteria. For the same reasons, the occurrence of production other than that by bacteria could be completely excluded under suboxic conditions.

\section{Uptake and release of DCAA}

There was no continuous trend during the $98 \mathrm{~h}$ of incubations in the net release of about $9 \mathrm{nmol} \mathrm{cm} \mathrm{cm}^{-2} \mathrm{~d}^{-1}$ of most of the individual DCAA. Concentrations remained at about $0.3 \mu \mathrm{M}$ (Fig. 4). DFAA were in the same range as those of DCAA but showed greater variations. Only concentrations of glycine were 4 times greater than those of most DCAA at the beginning of both oxic and suboxic incubations and decreased during the first $50 \mathrm{~h}$ by a factor of about 2. The constancy in DAA including leucine was in contrast to the potential proteolytic release determined from the EEA, which decreased between 8 - and 17 -fold during oxic and suboxic incubations (Table 1). Furthermore, at similar EEA under different redox conditions, concentrations of individual DCAA determined under anoxic conditions always remained below $0.3 \mu \mathrm{M}$ and were only $1 / 4$ to $1 / 2$ of those found during oxic and suboxic conditions. Even if our EEA measurements are not generally representative of the amino-acid-splitting enzymes present, they show that the concentrations of individual DAA might not simply depend on the EEA activity. The same is true for the microbial uptake, because at these DAA concentrations uptake rates for most of the individual amino acids would be saturated (Crawford et al. 1974, Suttle et al. 1991, Krämer 1994). Therefore, the observed accumulation of dissolved glycine might be produced during a selective decomposition of particulate matter enriched in glycine as is the case for cell wall material of diatoms (Fig. $4 \mathrm{a}, \mathrm{b}$ ). 

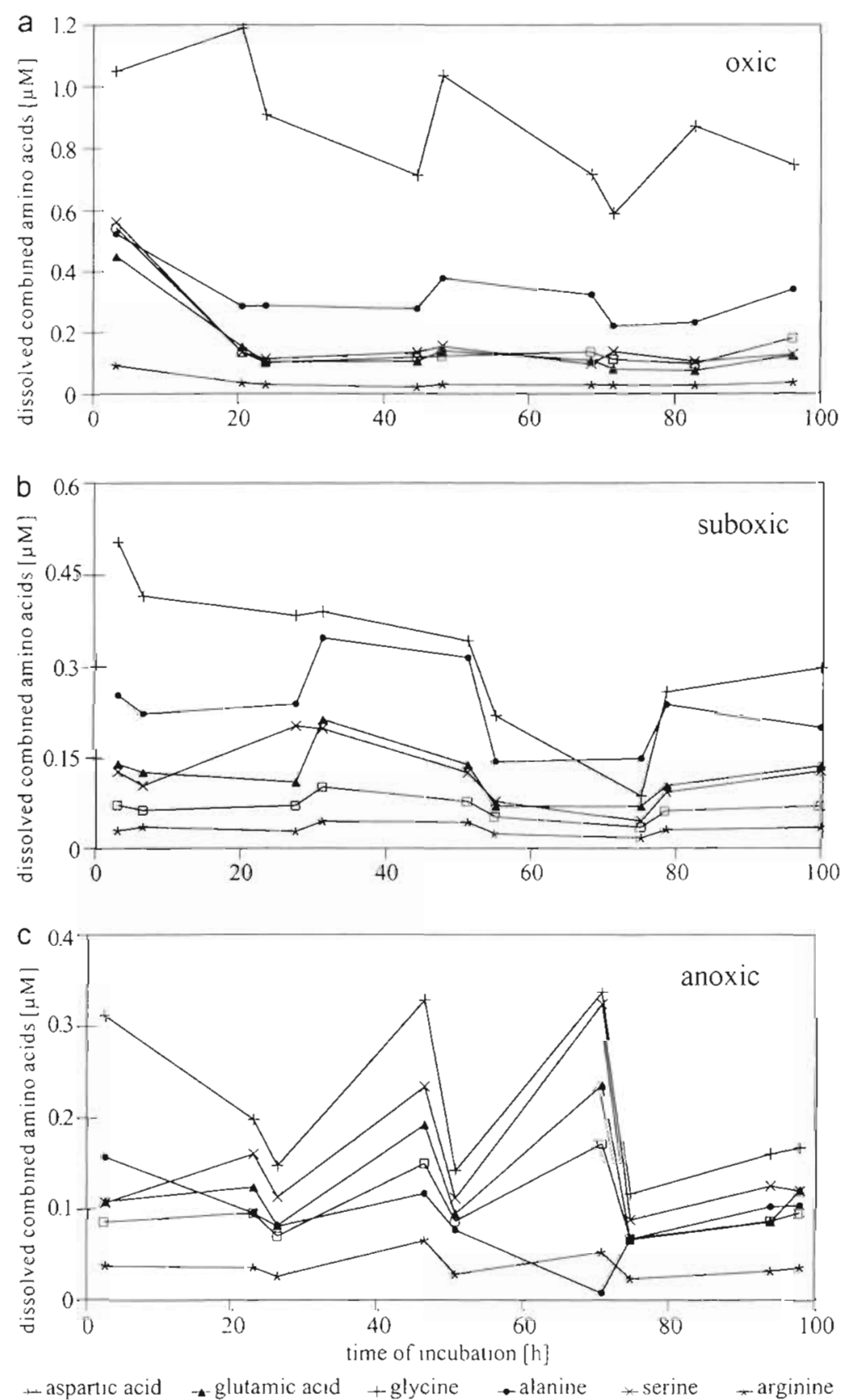

Fig. 4. Laboratory studies. Concentrations of individual dissolved combined amino acids (DCAA) in the water underlying the layer of aggregated seston from the Elbe estuary during (a) oxic, (b) suboxic and (c) anoxic incubations in July 1995. August 1994 and September 1994, respectively. Using the factor of 0.03 , the DCAA concentrations can be converted into

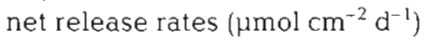

\section{Field studies}

Because field data were obtained at different sampling sites and during different years, a direct comparison of concentrations is difficult. Furthermore, it has to be taken into account that, in the part of Elbe estuary influenced by the tides, both sedimentation and resus. pension processes and the upstream transport of SPM during flood tide can cause great fluctuations in particulate matter concentrations on a scale of meters (Michaelis 1983, Schoer 1990). In both cases, highly degraded organic and inorganic matter is mixed with the seston during the prevailing downstream transport resulting in a dilution of the proportions of substances in the particulate matter. The impact of such a mixing is greatest when the seston concentration is low, as it was during the field study in May 1994. We therefore used mostly changes in concentrations and ratios along the longitudinal profile of the Elbe estuary to describe degradation processes.

In May 1993 and May 1994, O2 concentrations in the water entering the Elbe estuary decreased and minimum values were reached below $\mathrm{km} 630$ (Fig. 5b, c). This depletion in $\mathrm{O}_{2}$ along the longitudinal profile of the Elbe estuary was produced by heterotrophic oxygen consumption and was not found in March 1993, when maximum microbial activities determined as EEA were 4 times smaller (Fig. 5a). Likewise, in May 1993 and May 1994 rapid degradation of fresh phytoplankton upstream of $\mathrm{km} 630$ was indicated by the decrease of the chl $a: C$ ratio from 9 and 8 to 0.5 and $2 \mu \mathrm{g} \mathrm{mg}^{-1}$, respectively (Table 2). Decomposition of fresh phytoplankton material was further suggested by selective use of PCAA as substrate, and the PCAA content in relation to total POC decreased in the sedimenting seston from about 40 to $2 \%$ in May 1993 , and 25 to $5 \%$ in May 1994 (Fig. 5b, c). C:N ratios mostly did not follow degradation of PCAA and only little changes were found along the longitudinal profile (Table 2). The constant increase of the C:N ratios in May 1993 downstream of $\mathrm{km} 626$ reflects decomposition of organic matter that was found to adsorb ammonium, and the amount of extractable $\mathrm{NH}_{4}{ }^{+}$decreased from about 5 to below 1\% (Table 2), while dissolved ammonium concentrations remained constant at about $7 \mu \mathrm{M}$. The same tendency of the C:N to increase when the amount of extractable $\mathrm{NH}_{4}{ }^{+}$markedly decreased was also found in May 1994 between km 639 and 645.5 (Table 2).

Since primary production is inhibited between $\mathrm{km}$ 610 and 670 , there was no constant source of fresh particulate material within the region. Inputs of fresh 

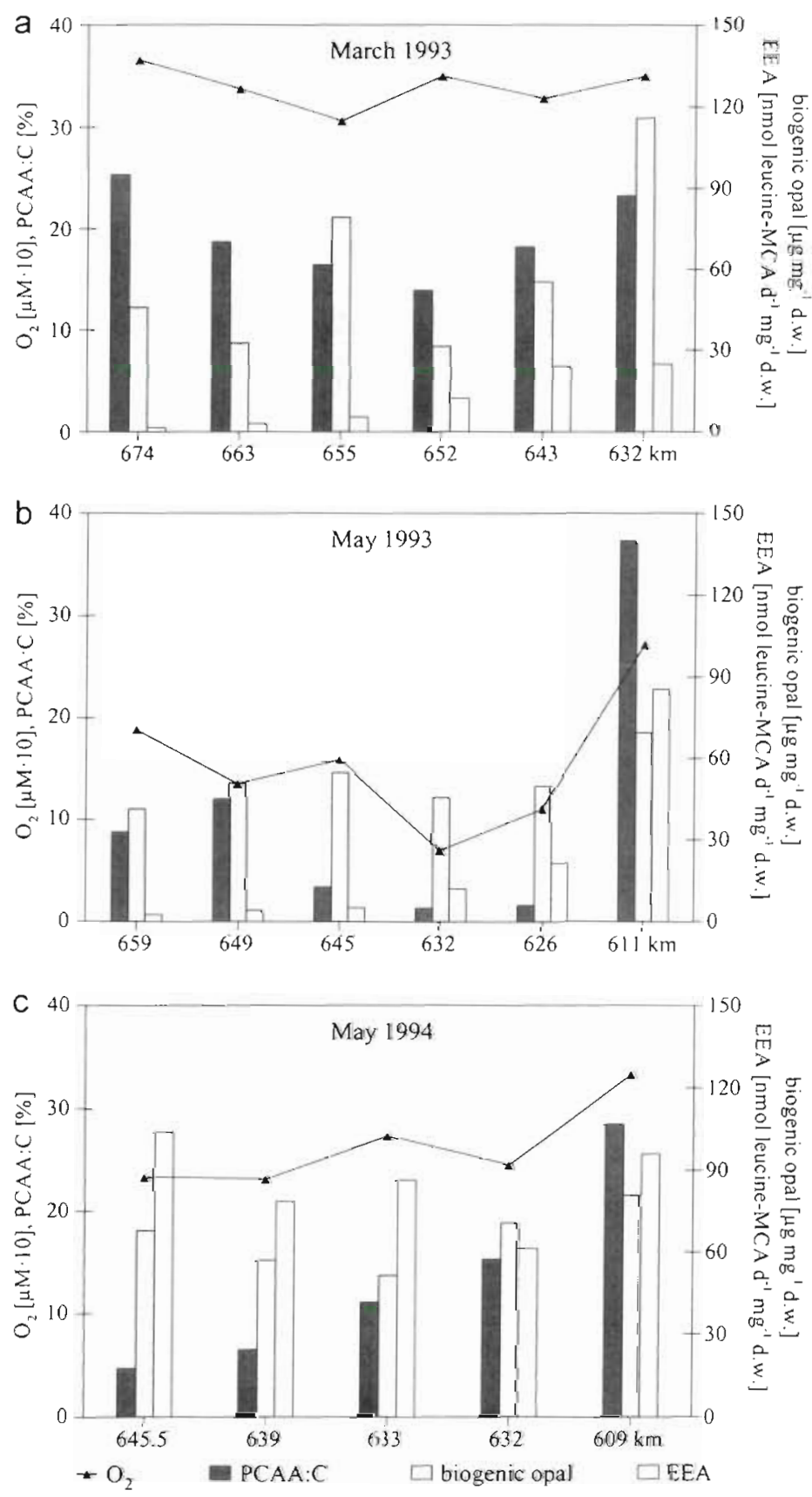

Fig. 5. Field studies. Ratio of PCAA:C and the amount of biogenic opal in the sedimenting seston, and concentrations of dissolved $\mathrm{O}_{2}$ and extracellular proteolytic enzyme activities (EEA) in the surface water along a longitudinal profile in the Elbe estuary in (a) March 1993. (b) May 1993 and (c) May 1994

organic matter from small streams flowing into the Elbe could be excluded from the decrease of the absolute concentrations of PCAA along the longitudinal profile (data not shown). Thus, progressive decomposition of the seston material occurred during transport downstream, which was coupled with specific changes in the composition of the PCAA in the
Table 2. Characterization of sed. PM from longitudinal profiles of the Elbe estuary by $\mathrm{C}: \mathrm{N}$, chl $\mathrm{a}: \mathrm{C}$ and adsorbed $\mathrm{NH}_{4}{ }^{*}$ of total $\mathrm{N}(\%)$ during surveys in March 1993, May 1993 and May 1994. -: no measurement

\begin{tabular}{lrrc|}
$\begin{array}{lrll}\text { Station } \\
(\mathrm{km})\end{array}$ & C:N & chl $a: \mathrm{C}$ & $\begin{array}{c}\text { Adsorbed } \\
\mathrm{NH}^{+}{ }^{+} \text {of } \mathrm{N}\end{array}$ \\
\hline $\begin{array}{lrl}\text { March } 1993 \\
674\end{array}$ & 9.7 & 1.07 & 0.35 \\
663 & 10.5 & 1.24 & 0.08 \\
655 & 9.3 & 0.37 & 0.32 \\
652 & 9.5 & 0.42 & 0.80 \\
643 & 10.2 & 0.19 & 0.33 \\
632 & 11.1 & 0.12 & 1.16 \\
May 1993 & & & \\
659 & 14.6 & 0.31 & 0.16 \\
649 & 13.3 & 0.39 & 0.30 \\
645 & 12.7 & 0.88 & 0.90 \\
632 & 11.0 & 0.59 & 1.26 \\
626 & 11.0 & 2.29 & 5.50 \\
611 & 8.0 & 9.00 & 2.84 \\
May 1994 & & & \\
645.5 & 9.6 & 3.27 & 0.17 \\
639 & 8.6 & 3.33 & 1.39 \\
633 & 8.8 & 4.27 & - \\
632 & 9.6 & 2.29 & 0.70 \\
609 & 6.0 & 8.02 & 0.09 \\
\hline
\end{tabular}

sedimenting seston (Fig. 6). In May 1993, between $\mathrm{km} 611$ and 645, the amounts of glycine and serine increased, while those of aspartic and glutamatic acid decreased. Downstream of $\mathrm{km} 645$, similar to the laboratory experiments described above, there was selective use of PCAA rich in glycine and serine and poor in aspartic and glutamatic acid, such that the amino acid composition of the seston reverted toward that of the PCAA of phytoplankton and/or bacterioplankton. The same was true during May 1994; seston entering the Elbe estuary had already been significantly enriched in glycine and serine and depleted of aspartic and glutamatic acid compared to living phytoplankton, which indicated an advanced state of decomposition. This situation was only poorly reflected by chl a:C and EAA, which remained high compared to May 1993. The differences in chl a:C and EAA between the different years can be partly explained by the 5to 10-fold lower SPM concentration during May 1994, as discussed above. During March 1993, the biochemical composition of sedimenting seston remained unaffected by biological production and consumption processes along the whole longitudinal profile. Chl a:C ratios remained below $2 \mathrm{\mu g} \mathrm{mg}^{-1}$, the $\mathrm{C}: \mathrm{N}$ ratio was about 10 , and the amount of extractable $\mathrm{NH}_{4}{ }^{+}$remained below $1.2 \%$ (Table 2). 

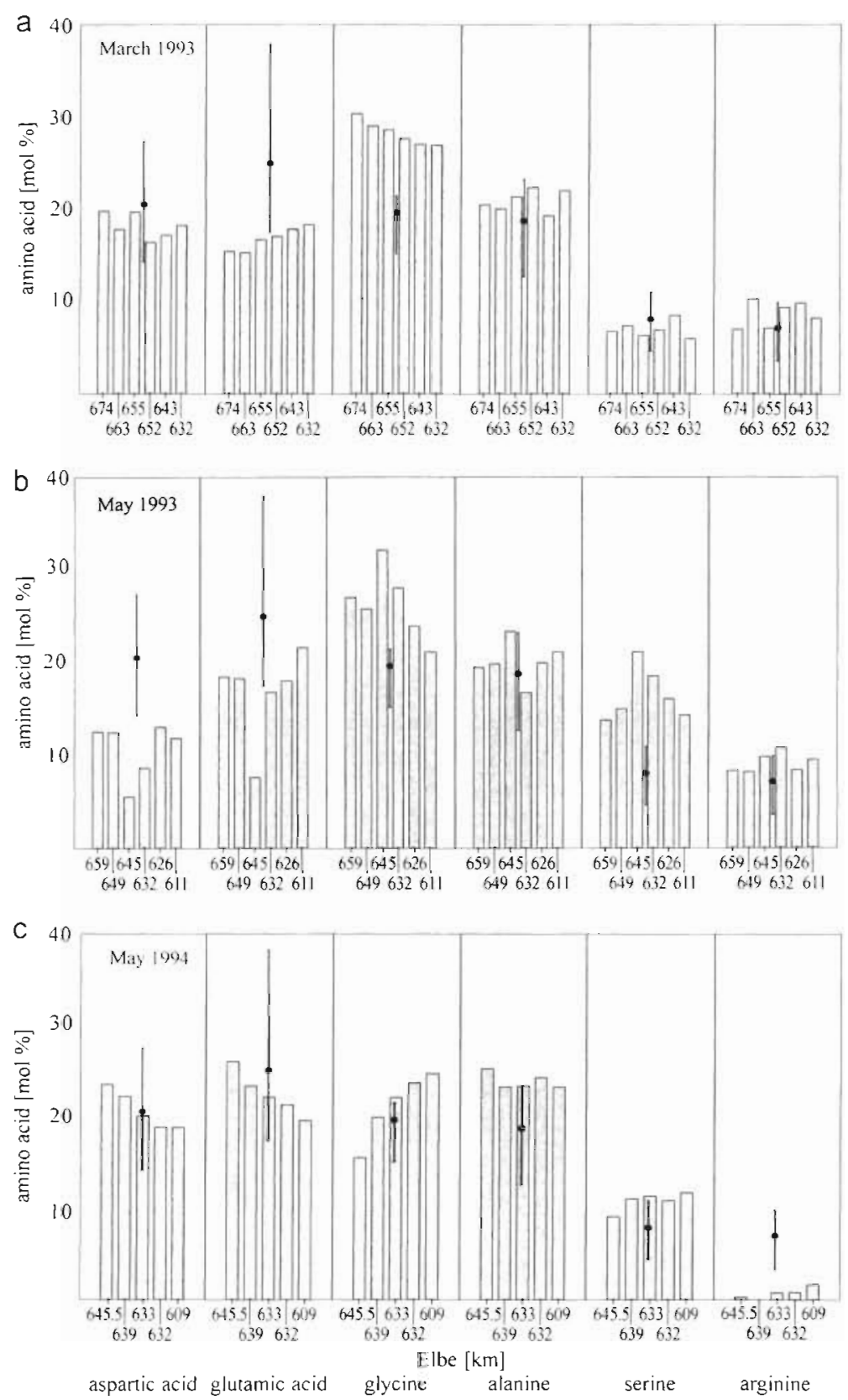

Fig. 6. Field studies. Relative abundances in molar percentages of individual amino acids in sedimenting seston in the surface water along a longitudinal profile in the Elbe estuary in (a) March 1993, (b) May 1993 and (c) May 1994 compared to their proportions in phytoplankton (point: mean; error bars: ranges) as reported by Cowie \& Hedges (1992)

Furthermore, PCAA concentrations mostly accounted for less than $20 \%$ of the $\mathrm{POC}$, and the amino acid composition remained typical for degraded material of sedimentary origin (Fig. 6a). Both during March and May, dissolution of biogenic opal occurred independently of heterotrophic microbial activities and concentrations decreased within the longitudinal profile by more than $40 \%$ (Fig 5).

\section{DISCUSSION}

The results of the laboratory studies on the degradation of POC were obtained using seston from the Elbe estuary which consisted only of aggregates $>100 \mu \mathrm{m}$ in diameter and was free of larger planktonic organisms. Most of the seston used consisted of inorganic matter, as indicated by a POC content below $10 \%$. The organic carbon contained about $12 \%$ PCAA, which is close to the average of $10 \%$ in coastal marine sediments (Cowie et al. 1992) and much below the 25 to $30 \%$ found in pure cultures of diatoms (Cowie et al. 1992, Harvey et al. 1995). However, chl a:C ratios above 16 and chl a:fucoxanthin ratios below 2.2 indicated that much of the POC was phytoplankton, which was dominated by diatoms (Hunter \& Laws 1981). The chl a: fucoxanthin ratio is close to the 1.7 found in pure cultures of Actinocyclus normanii and Thalassiosira pseudonana, both dominant diatom species in the Elbe estuary (Wolfstein \& Kies 1995, F. Edelkraut pers. comm.). The preponderance of diatoms in the Elbe estuary was confirmed by additional investigations during our field studies in May 1993 and May 1994 when diatoms were found by microscopic examination to account for between 75 and $95 \%$ of all algal cells in the sedimenting seston (Wolfstein \& Kies 1995). An advanced microbial colonization of the seston was always observed, with the number of particle-bound bacteria of a similar order of magnitude as that for the free-living ones, $10^{6}$ cells $\mathrm{ml}^{-1}$ (Böttcher et al. 1995). Between $10^{2}$ and $10^{3}$ cells $\mathrm{ml}^{-1}$ were comprised by lithotrophic bacteria (Schäfer \& Harms 1995).

\section{Diversity of respiration processes}

Nearly all the microbial respiration processes in the Elbe estuary described in the literature occurred in seston obtained from open, aerobic water, which had the capacity for microbial reduction of oxygen, nitrate, manganese and ferric iron. These microbial processes were rapidly initiated within the seston layer when oxic, suboxic and anoxic conditions were induced (Fig, 2). The capacity for anaerobic microbial processes reflects either (1) that the material was resuspended sediment, or (2) that anaerobic processes occur within the open water of the 
Elbe estuary. A previous study, in which suboxic microbial processes were found to occur in the Elbe estuary when oxygen concentrations in the open water decreased to about $95 \mu \mathrm{M} \mathrm{O}_{2}$ (Kerner \& Edelkraut 1995), supports the second explanation. Likewise, no capacity for sulfate reduction was detected in the seston but was found in anaerobic sediments of the Elbe estuary (Tiedemann \& Wilken 1987, Kerner 1993). In contrast, even obligate sulfate reducers have been found in marine snow aggregates, which, however, can reach several $\mathrm{cm}$ in diameter and therefore be subject to more reduced conditions than those in estuarine aggregates of only a few mm in diameter (Eisma 1993, Shanks \& Reeder 1993). Even the reports on sulfate reducers associated with marine snow do not provide information on whether sulfate reduction really occurs in situ. In general, this cannot be determined by field studies because the end products of anaerobic processes are difficult to detect when aerobic conditions prevail in the surrounding water. For the same reason, the respiration rates determined in the aggregated seston can only be compared directly with those available from biofilms. Mean rates of $12 \mu \mathrm{mol} \mathrm{cm} \mathrm{cm}^{-3} \mathrm{~d}^{-1}$ for total oxygen consumption and $21 \mu \mathrm{mol} \mathrm{cm}^{-3} \mathrm{~d}^{-1}$ for nitrate reduction detected in the seston aggregates were quite similar to those found for compact microbial communities in biofilms (Nielsen et al. 1990). However, when glucose was added, respiration rates in the biofilms increased by a factor of 3 to 1000 (Kühl \& Jørgensen 1992). DOC present in the Elbe estuary might similarly enhance respiration rates within the seston aggregates, which would limit oxic degradation processes in aggregates suspended in aerobic water to the upper 200 to $400 \mu \mathrm{m}$ of the particle-water interface. Hence, the greater amount of degradation in natural aggregates would proceed via suboxic processes, resulting in changes of the POM composition described below. To clarify how close our rates for oxygen consumption were to the in situ situation, we compared our results with the biological oxygen demand $\left(\mathrm{BOD}_{7}\right)$ measured in the Elbe water at km 630 in May 1993 (Klages 1995). The good agreement between the $\mathrm{BOD}_{7}$ of 0.4 with our mean rate of $0.2 \mathrm{mg} \mathrm{O}_{2} \mathrm{~g}^{1}$ dry wt h ${ }^{1}$ suggests similar conditions in our device.

\section{Changes in substrate availability}

While the importance of oxygen for sedimentary organic matter preservation is debated (Lee 1992, Canfield 1994), it is clear from our study that its concentration is also important in determining whether the rate and amount of organic matter decomposition in seston aggregates is coupled to oxygen respiration. At $\mathrm{O}_{2}$ concentrations of below $56 \mu \mathrm{M}$ in the seston layer, ap- proximately equal amounts of $\mathrm{POC}$ mineralization were supported by oxygen and nitrate respiration. A limitation in substrate availability was suggested only for oxygen, with the respiration rate decreasing after $48 \mathrm{~h}$ of continuous incubation while nitrate respiration increased during $98 \mathrm{~h}$ of incubation. This increase was not explained by the oxygen concentration within the seston aggregates; the $\mathrm{O}_{2}$ concentration remained constant due to changes in nitrification, which accounted for $29 \%$ of the total oxygen consumption (Fig. 2a). Constant rates during $98 \mathrm{~h}$ of suboxic incubation suggest nitrate respiration to be less limited by substrate availability than oxygen respiration. Previous studies during which the oxygen concentrations were above $95 \mu \mathrm{M} \mathrm{O}_{2}$ showed that the supply of organic substrates limited oxygen respiration after about $120 \mathrm{~h}$, when nitrification accounted for almost the entire oxygen consumption (Kerner \& Gramm 1995). With respect to processes in the field, present findings show that significant nitrate reduction might occur even in degraded seston exposed to suboxic conditions, a situation that could occur after sedimentation onto anaerobic sediments. Under anoxic conditions, however, when POC degradation was restricted to both ferric iron and manganese reduction in the seston, rates were only about $1 \%$ of those under suboxic conditions and further decreased to about $0.5 \%$ after $98 \mathrm{~h}$, due to the substrate specificity of these respiration processes (Fig. 2c). Anoxic degradation coupled to fermentation was restricted to the first $48 \mathrm{~h}$ of incubation, when rates similar to those under suboxic and oxic conditions were reached, as indicated by both the ammonium and $\mathrm{CO}_{2}$ budgets. Some of the organic substances produced in this way are used as substrates for respiration but showed only little impact on ferric iron and manganese reduction in the seston aggregates. In the literature, the potential of fermentation processes is mainly overlooked, although they seem important processes in suboxic mud flat sediments where fermentation has been considered to control iron and manganese reduction (Kerner 1993). Within the oxic-anoxic interfaces of sediment surface layers, fermentation has been found to produce an increase in oxygen respiration (Kerner \& Gramm 1995). In coastal marine sediments fermentation allows sulfate reduction to occur at high rates to which most of the mineralization is coupled. The substrates thereby used are always low molecular weight compounds and nearly all of these are known to be fermentation products (Widdel 1988).

\section{Selective utilization of POC}

Preferential mineralization of PCAA within the mixture of organic matter, as described for marine sedi- 
ments and material from sediment traps, was also detected in the seston aggregates, where the proportion of PCAA in the POC decreased from 12 to below $2 \%$ (Henrichs \& Farrington 1987, Lee et al. 1987, Burdige \& Martens 1988). The amino acids that remained in the seston after both oxic and suboxic degradation were not refractory but consisted mainly of active bacterial biomass (see below). Similar efficiencies were found only in an experiment by Harvey et al. (1995), who mimicked the natural aerobic environment of sedimented diatoms or cyanobacteria in a flowthrough system in which no nutrient limitation occurred and end products were exchanged continuously. Because other studies generally used static incubations, Harvey et al. (1995) interpreted the nearly complete mineralization of phytoplankton debris within about 20 to $30 \mathrm{~d}$ to indicate a sufficient nutrient supply and a dilution of metabolites in his experiments. A similar time for the degradation of most labile substances in estuarine phytoplankton detritus was found in static slurry incubations by using oxygen consumption as the indicator (Hargrave \& Phillips 1989). However, in our experiments the decay time for 84 to $88 \%$ of the PCAA under both oxic and suboxic conditions was only $56 \mathrm{~h}$ after the seston had been incubated in a layer. In the field, when microbial processes determined along the freshwater profile of the Elbe estuary were high in May 1993 and May 1994, very similar efficiencies of 95 and $83 \%$, respectively, were calculated (Fig. 5). Also, the time in which degradation of PCAA occurred in the field was in good agreement with our laboratory experiments. Assuming that the transport of the SPM along the longitudinal profile of the Elbe estuary was similar to the movement of the water mass, decomposition processes would have been completed within 2 to $4 \mathrm{~d}$. Similarly, in studies of marine and estuarine sediment trap material, amino acids produced by primary production were found to decrease by up to $80 \%$ while sinking through the upper 50 to $100 \mathrm{~m}$ of the ocean (Lee \& Cronin 1982, Montani \& Okaichi 1985). Since most of the sedimenting particles are about $1 \mathrm{~mm}$ in diameter and sedimentation rates are known to be about $50 \mathrm{~m} \mathrm{~d}^{-1}$, the time it takes for the PCAA to decompose must only be about 2 d (Dyer 1986). In the literature, the rapid decay of PCAA within seston aggregates is explained as the high exoenzymatic activities and high densities and growth rates of the particle-bound microorganisms, as described for marine and limnic flocs (Smith et al. 1992, Grossart \& Simon 1993, Kepkay 1994). However, present results show that elimination of PCAA within the seston aggregates from the Elbe estuary occurred independently of the differences in bacterial activities during the same periods of both oxic and suboxic incubation. Thus, under these conditions, degradation of
PCAA in the seston aggregates always occurred at a maximum rate, which was controlled by the high microbial availability in the PCAA.

Another phytoplankton compound that can be quickly degraded under oxic conditions by a variety of diagenetic processes within the water column and surface sediments is chlorophyll (Sun et al. 1993). Present field studies showed that in the Elbe estuary at oxygen concentrations of usually well above $100 \mu \mathrm{M} \mathrm{O}_{2}$, chl a was degraded preferentially to the bulk of the organic material, and the chl a:C ratio decreased below 3 Using seston from the Elbe, Kerner \& Gramm (1995) observed that $70 \%$ of the chl a was decomposed within $30 \mathrm{~h}$ after the material had formed aggregates, when oxygen concentrations were well above $95 \mu \mathrm{M}$. In the laboratory experiments described here, although the chl a concentration decreased considerably under all experimental conditions, the chl a:C ratios remained comparatively constant when oxygen concentrations in the seston layer were below $56 \mu \mathrm{M}$ (Table 1). A further decrease in the oxygen concentration to below $31 \mu \mathrm{M}$, as well as during suboxic conditions, an increase in the chl a:C ratios to above 36 was observed, indicating that more chl a than POC had accumulated during degradation. The similarity of the results during different years indicates that differences in the biochemical composition had little impact on the degradability of chl a. The differences in chl a degradation are probably due to the dissimilar processes employed by the heterotrophic organisms under different redox conditions. Therefore, chl a degradation seems very sensitive to changes at low oxygen concentrations, and an increase in the chl a:C ratio during degradation might be indicative of oxygen concentrations within the seston aggregates below a threshold value of about $60 \mu \mathrm{M}$.

\section{Degradation of refractory material}

From ammonium uptake we calculated that at the end of both oxic and suboxic incubations, about $10 \%$ of the PN had been derived from newly produced bacterial biomass, assuming that ammonium accounted for $50 \%$ of the total $N$ demand (Keil \& Kirchman 1991). Because in $\mathrm{NH}_{4}{ }^{+}$has been reported to sustain from 8 to $90 \%$ of the bacterial $\mathrm{N}$ demand in estuarine bacteria, our calculations might be either overestimated or underestimated by a factor of 6 or 2, respectively (Kroer et al. 1994, Hoch \& Kirchman 1995, Middelboe et al. 1995). An underestimation could be excluded because of the findings that the $\mathrm{N}$ in the newly formed bacterial biomass equaled the amounts of $N$ in the PCAA detected at the completion of oxic and suboxic incubations (Table 1). Likewise, during this period, the PCAA in the phytoplankton must have been com- 
pletely decomposed. This even includes the cell wall material of the diatoms. In the literature, the cell wall material of diatoms has been reported to resist degradation, and increasing amounts of serine and glycine in the particulate matter with increasing depth in the water and sediment have been said to be indicative of an advanced state of decay (Sigleo et al. 1983, Burdige \& Martens 1988, Faganeli 1989). Lee et al. (1987) even used the persistence of the glycine-rich PCAA material to estimate the proportion of resuspended sediments in the total SPM in Lake Greifen, Switzerland. The results of the present study clearly show that degradation of both inorganic and organic compounds in the cell wall material of diatoms occurs in seston aggregates from the Elbe within $56 \mathrm{~h}$ under both oxic and suboxic conditions. Since the PCAA in the cell lumen are more easily degraded than that in the cell wall, there was a characteristic sequence in the relative amounts of glycine, serine, aspartic and glutamatic acid. This sequence can be used to characterize different states of decay. At an intermediate state of decay, which was detected only during our field experiments, most of the PCAA have been degraded, but the protein structure of the cell wall remains intact. This results in increases in the relative amounts of glycine and serine and a decrease in those of aspartic and glutamatic acid (Fig. 6b). Further degradation of seston material enriched in this PCAA pool was followed both in laboratory incubations and field experiments and brought about similar changes in PCAA composition with decreasing relative amounts of glycine and serine and an increase in those of aspartic and glutamatic acid (Figs. 3a, b \& 6b, c). It is coupled with an accumulation of dissolved glycine. When the degradation of the PCAA, except that in newly formed bacterial biomass, is completed, the PCAA composition becomes similar to that of bacterioplankton. At this stage of decomposition, about $50 \%$ of the biogenic opal had been dissolved at a dissolution rate coefficient equivalent to about $0.2 \mathrm{~d}^{-1}$, which is and similar to the maximum rates of 0.05 to $0.2 \mathrm{~d}^{-1}$ from silica dissolution of small centric diatoms at $20^{\circ} \mathrm{C}$ (Nelson et al. 1976). In addition to showing that silica is rapidly recycled from the seston aggregates, this finding demonstrates that diatom cell walls are not of refracatory nature and even their inorganic compounds are subject to rapid decomposition processes.

Our laboratory results showed that only anoxic conditions can induce a general resistance of proteins to diagenetic decomposition. Fabiano \& Danavaro (1994) came to the same conclusion examining sediments, and molar fractions of glycine and serine have been found to increase with depth in anoxic coastal marine sediments (Burdige \& Martens 1988). Similarly, no changes in composition of the PCAA were detected during the settling of fresh phytoplankton in the stratified Potomac estuary, Maryland, USA, where an enrichment of glycine and alanine and a depletion of aspartic and glutamatic acid occurred only during sedimentary processes (Sigleo \& Schulz 1993). However, in most studies the impact of anoxic conditions cannot be separated from the many other factors which might also influence decomposition of proteins in cell walls of diatoms. These include lack of easily degradable organic matter, adsorption to humic substances, competition for $N$ sources, complex formation with a number of other compounds, lack of specific exoenzymes, and lack of specific micronutrients. Such ambiguity could be partly avoided in future studies on microbial cycling of POC by including both the determination of the respiration rates to characterize the availability of organic substrates and changes in the biochemical composition.

In conclusion, our evidence for the effect of aggregation of the seston on the rate and efficiencies of microbial degradation of phytoplankton has some important implications at the ecological level. The net release of ammonium during suboxic degradation might have consequences for the nutrient status of the plankton community, and observations of the seston aggregates should be included in discussions of competition for inorganic nutrients between bacteria and phytoplankton (Kirchman 1994). For aquatic environments in which phytoplankton decomposition within aggregates is rapid, heterotrophic microbial control of the abundance of phytoplankton might be overlooked and zooplankton grazing overestimated. Determining amino acid composition in aggregated seston rich in diatoms offers great potential as a tracer of the state of microbial degradation and availability of POC.

Acknowledgements. This work was supported by the Deutsche Forschungsgemeinschaft with a Habilitation and PhD scholarship for M.K. and S.Y., respectively. We thank M. S. Adams (University of Wisconsin-Madison, USA) and C. Heckmann (University of Hamburg, Germany) for the critical review of the English version of our paper.

\section{LITERATURE CITED}

Alldredge AL, Cohen Y (1987) Can microscale chemical patches persist in the sea? Microelectrode study of marine snow, fecal pellets. Science 235:689-691

Arge (Arbeitsgemeinschaft für die Reinhaltung der Elbe) (1989-1993) Wassergütedaten der Elbe von Schnackenburg bis zur See-Zahlentafel. Wassergütestelle Elbe, Hamburg

Böttcher B, Dittberner P, Rath G, Schäfer B, Zörner S, Koops HP (1995) A case study on the oxygen budget in the freshwater part of the Elbe estuary. 4. Bacterial population shifts and rising oxygen deficiencies. Arch Hydrobiol Suppl 110(1):55-76

Burdige DJ, Martens CS (1988) Biogeochemical cycling in an 
organic-rich basin: 10. The role of amino acids in sedimentary carbon and nitrogen cycling. Geochim Cosmochim Acta 52:1571-1584

Canfield DE (1994) Factors influencing organic carbon preservation in marine sediments. Chem Geol 114:315-329

Coffin RB, Connolly JP, Harris PS (1993) Availability of dissolved organic carbon to bacterioplankton examined by oxygen utilization. Mar Ecol Prog Ser 101:9-22

Cowie GL, Hedges JI (1992) Sources and reactivities of amino acids in a coastal marine environment. Limnol Oceanogr 37:703-724

Cowie GL, Hedges JI, Calvert SE (1992) Sources and reactivities of amino acids, neutral sugars, and lignin in an intermittently anoxic marine environment. Geochim Cosmochim Acta 56:1963-1978

Crawford CC, Hobbie JE, Webb KL (1974) The utilization of dissolved free amino acids by estuarine microorganisms. Ecology 55:551-563

Daemen EAM (1986) Comparison of methods for the determination of chlorophyll in estuarine sediments. Neth J Sea Res 20:21-28

Demaster DJ (1981) The supply and accumulation of silica in the marine environment. Geochim Cosmochim Acta $45: 1715-1732$

Dugdale RC, Goering JJ (1967) Uptake of new and regenerated forms of nitrogen in primary productivity. Limnol Oceanogr 12:196-296

Dyer KR (1986) Coastal and estuarine sediment dynamics. Wiley, Chichester

Dyer KR (1988) Fine sediment particle transport in estuaries. ln: Dronkers J, van Leussen WB (eds) Physical processes in estuaries. Springer, Berlin, p 295-310

Eisma D (1993) Suspended matter in the aquatic environment. Springer, Berlin

Fabiano M, Danovaro R (1994) Composition of organic matter in sediments facing a river estuary (Tyrrhenian Sea): relationship with bacteria and microphytobenthic biomass. Hydrobiologia 277:71-84

Faganeli J (1989) Sedimentation of particulate nitrogen and amino acids in shallow coastal waters (Gulf of Trieste, Northern Adriatic). Mar Chem 26:67-80

Froelich PN, Klinkhammer GP, Bender ML, Luedtke NA, Heath GR, Cullen D, Dauphin P. Hammond D, Hartman B, Maynard V (1979) Early oxidation of organic matter in pelagic sediments of the eastern equatorial Atlantic: suboxic diagenesis. Geochim Cosmochim Acta 43:1075-1090

Furlong ET, Carpenter R (1988) Pigment preservation and mineralization in oxic coastal marine sediments. Geochim Cosmochim Acta 52:87-99

Grasshoff K, Erhardt M, Kremling K (1983) Methods of sea water analysis. Verlag Chemie, Weinheim

Grossart HP, Simon M (1993) Limnetic macroscopic organic aggregates (lake snow): occurrence, characteristics, and microbial dynamics in Lake Constance. Limnol Oceanogr 38:532-546

Hargrave BT, Phillips GA (1989) Decay times of organic carbon in sedimented detritus in a macrotidal estuary. Mar Ecol Prog Ser 56:271-279

Harvey HR, Tuttle JH, Bell JT (1995) Kinetics of phytoplankton decay during simulated sedimentation: changes in biochemical composition and microbial activity under oxic and anoxic conditions. Geochim Cosmochmm Acta 59: $3367-3377$

Head EJH, Hargrave BT, Subba Rao DV (1994) Accumulation of a pheophorbide a-like pigment in sediment traps during late stages of a spring bloom: a product of dying algae? Limnol Oceanogr 39:176-181
Hecky RE، Mopper K, Kilham P, Degens ET (1973) The amino acid and sugar composition of diatom cell-walls. Mar Biol 19:323-331

Hedges JI, Cowie GL, Richey JE, Quay PD, Benner R, Strom M. Forsberg BR (1994) Origins and processing of organic matter in the Amazon River as indicated by carbohydrates and amino acids. Limnol Oceanogr 39:743-761

Hedges JI, Keil RG (1995) Sedimentary organic matter preservation: an assessment and speculative synthesis. Mar Chem 49:81-115

Henrichs SM, Farrington JW (1987) Early diagenesis of amino acids and organic matter in two coastal marine sediments. Geochim Cosmochim Acta 51:1-15

Hoch MP, Kirchman DL (1995) Ammonium uptake by heterotrophic bacteria in the Delaware estuary and adjacent coastal waters. Limnol Oceanogr 40:886-897

Hoppe HG (1983) Significance of exoenzymatic activities in the ecology of brackish water measurements by means of methylumbelliferyl-substances. Mar Ecol Prog Ser 11 299-308

Hunter BL, Laws EA (1981) ATP and chlorophyll a as estima tors of phytoplankton carbon biomass. Limnol Oceanogr 26:944-956

Jørgensen BB (1977) Bacterial sulfate reduction within reduced microniches of oxidized marine sediments. Mar Biol $41: 7-17$

Keil RG, Kirchman DL (1991) Contribution of dissolved free amino acids and ammonium to the nitrogen requirements of heterotrophic bacterioplankton. Mar Ecol Prog Ser 73: $1-10$

Kepkay PE (1994) Particle aggregation and the biological reactivity of colloids. Mar Ecol Prog Ser 109:293-304

Kerner M (1993) Coupling of fermentation and respiration processes in an intertidal mud tlat of the Elbe estuary. Limnol Oceanogr 38:314-330

Kerner M, Edelkraut F (1995) Decomposition of organic matter in aggregated seston from the Elbe estuary: redox dependency and production of low molecular weight DOC compounds. Mar Ecol Prog Ser 123:281-293

Kerner M, Gramm H (1995) Changes in oxygen consumption at the sediment-water interface formed by settling seston from the Elbe estuary. Limnol Oceanogr 40:544-555

Kerner M, Kappenberg J, Brockmann U, Edelkraut F (1995) A case study on the $\mathrm{O}_{2}$ budget in the freshwater part of the Elbe estuary: 1 . The effect of changes in physico-chemical conditions on the oxygen consumption. Arch Hydrobiol Suppl 110(1):1-25

Kerner M, Krogmann D (1994) Partitioning of trace metals in suspended matter from the Elbe estuary fractioned by a sedimentation method. Neth J Sea Res 33:19-27

Kiørboe T, Hansen JLS (1993) Phytoplankton aggregate formation: observations of patterns and mechanisms of cell sticking and the significance of exopolymeric material J Plankton Res 15:993-1018

Kurchman DL (1994) The uptake of inorganic nutrients by heterotrophic bacteria. Microb Ecol 28:255-271

Klages D (1995) A case study on the $\mathrm{O}_{2}$ budget in the freshwater part of the Elbe estuary: 6. Potentials of oxygen demand in the longitudinal profile of the Elbe river Arch Hydrobiol Suppl 110(1):83-91

Krämer R (1994) Systems and mechanisms of amino acid uptake and excretion in prokaryotes. Arch Microbiol 162: $1-13$

Kroer N, Jørgensen NOG, Coffin RB (1994) Utilization of dissolved nitrogen by heterotrophic bacterioplankton: a comparison of three ecosystems. Appl Environ Microbiol 60: $4116-4123$ 
Kühl M, Jørgensen BB (1992) Microsensor measurements of sulfate reduction and sulfide oxidation in compact microbial communities of aerobic biofilms. Appl Environ Microbiol 58:1164-1174

Laws E (1984) Isotope dilution models and the mystery of the vanishing ${ }^{15} \mathrm{~N}$. Limnol Oceanogr 29:379-386

Lee C (1992) Controls on organic carbon preservation: the use of stratified water bodies to compare intrinsic rates of decomposition in oxic and anoxic systems. Geochim Cosmochim Acta 56:3323-3335

Lee C. Cronin C (1982) The vertical flux of particulate organic nitrogen in the sea: decomposition of amino acids in the Peru upwelling area and the equatorial Atlantıc. J Mar Res 40:227-251

Lee C. McKenzie JA, Sturm M (1987) Carbon isotope fractionation and changes in the flux and composition of particulate matter resulting from the biological activity during a sediment trap experiment in Lake Greifen, Switzerland. Limnol Oceanogr 32:83-96

Letelier RM, Bidigare RR, Hebel DV, Ondrusek M, Winn CD, Karl DM (1993) Temporal variability of phytoplankton community structure based on pigment analysis. Limnol Oceanogr 38:1420-1437

Loosdrecht van MCM, Lyklema J, Norde W, Zehnder AJB (1990) Influence of interfaces on microbial activity. Microb Rev 54:75-87

Lovley DR, Phillips E (1986) Organic matter mineralization with reduction of ferric iron in anaerobic sediments. Appl Environ Microbiol 51:683-689

Luther GW III, Giblin AE, Varsolona R (1985) Polarographic analysis of sulfur species in marine pore waters. Limnol Oceanogr 30:727-736

Michaelis W (1993) Untersuchungen zum Schwebstoff- und Schwermetalltransport in der Elbe. Report No. 83/E/39, GKSS-Forschungszentrum, Geesthacht, Germany

Middelboe M, Borch NH, Kirchman DL (1995) Bacterial utilization of dissolved free amino acids, dissolved combined amino acids and ammonium in the Delaware Bay estuary: effect of carbon and nitrogen limitation. Mar Ecol Prog Ser 128:109-120

Montani S, Okaichi T (1985) Amino acid variations in marine particles during sinking and sedimentation in HarimaNada, the Seto Inland Sea, Japan. In: Sigleo AC, Hattori A (eds) Marine and estuarine geochemistry. Lewis Publ. Chelsea, MI, p 15-27

Mopper K, Lindroth P (1982) Diel and depth variations in dissilved free amino acids and ammonium in the Baltic Sea determined by shipboard HPLC analysis. Limnol Oceanogr 27:336-347

Nelson DM, Goering JJ, Kilham SS, Guillard RRL (1976) Kinetics of silicic acid uptake and rates of silica dissolution in the marine diatom Thalassiosira pseudonana. I Physiol $12: 246-252$

Nielsen LP, Christensen PB, Revsbech NP, Sørensen J (1990) Dentrification and oxygen respiration in biofilm studied with a microsensor for nitrous oxide and oxygen. Microb Ecol 19:63-72

Poryvkina L, Babichenko S, Kaitala S, Kuosa H, Shalapjonok A. (1994) Spectral fluorescence signatures in the char-

Editorial responsibility: Otto Kinne (Editor), Oldendorf/Luhe, Germany acterization of phytoplankton community composition. J Plankton Res 16:1315-1327

Ratledge C (1994) Blochemistry of microbial degradation. Kluwer, Dordrecht

Richter G (1988) Stoffwechselphysiologie der Pflanzen. Thieme, Stuttgart

Rosenfeld JK (1979) Ammonium adsorption in nearshore anoxic sediments. Limnol Oceanogr 24:356-364

Schäfer B, Harms H (1995) A case study on the oxygen budget in the freshwater part of the Elbe estuary. 5. Distribution of different ammonia-oxidizing bacteria in the river Elbe downstream of Hamburg at low and normal oxygen concentrations. Arch Hydrobiol Suppl 110(1):77-82

Schoer JH (1990) Determination of the origin of suspended matter and sediments in the Elbe estuary using natural tracers. Estuaries 13:161-172

Shanks AL, Reeder ML (1993) Reducing microzones and sulfide production in marine snow. Mar Ecol Prog Ser 96:43-47

Sigleo AC, Hare PE, Helz GR (1983) The amino acid composition of estuarine colloidal material. Estuar Coast Shelf Sci $17: 87-96$

Sigleo AC, Schulz DJ (1993) Amino acid composition of suspended particles, sediment-trap material, and benthic sediment in the Potomac estuary. Estuaries 16:405-415

Smith DC, Simon M, Alldredge A, Azam F (1992) Intense hydrolytic enzyme activity on marine aggregates and implications for rapid particle dissolution. Nature 359: $139-142$

Sørensen J, Christensen D, Jørgensen BB (1981) Volatile fatty acids and hydrogen as substrates for sulfate-reducing bacteria in anaerobic marine sediment. Appl Environ Microbiol 42:5-11

Sun MY, Lee C, Aller RC (1993) Anoxic and oxic degradation of ${ }^{14} \mathrm{C}$-labeled chloropigments and a ${ }^{14} \mathrm{C}$-labeled diatom $1 n$ Long Island Sound sediment. Limnol Oceanogr 38 : $1438-1451$

Suttle CA, Chan AM, Fuhrman JA (1991) Dissolved free amino acids in the Sargasso Sea: uptake and respiration rates, turnover times, and concentrations. Mar Ecol Prog Ser 70:189-199

Sweerts JPRA, Kelly CA, Rudd JWM, Hesslein R, Cappenberg TE (1991) Similarity of whole-sediment molecular diffusion coefficients in freshwater sediments of low and high porosity. Limnol Oceanogr 36:335-342

Tiedemann H, Wilken RD (1987) Sulphate reduction in the sediments of the tidal influenced Elbe River. Report No. E53, GKSS-Forschungszentrum, Geesthacht

Widdel $F$ (1988) Microbiology and ecology of sulfate- and sulfur-reducing bacteria. In: Zehnder AJB (ed) Biology of anaerobic microorganisms. Wiley, New York, p 469-585

Wofsy SC (1983) A simple method to predict extinction coefficients and phytoplankton biomass in eutrophic waters Limnol Oceanogr 28:1144-1155

Wolfstein K, Kies L (1995) A case study on the oxygen budget in the freshwater part of the Elbe estuary. 3. Variations in phytoplankton pigments in the Elbe before and during the oxygen minima in 1992 and 1993. Arch Hydrobiol Suppl 110(1):39-54

Submitted: February 14, 1997; Accepted: August 20, 1997 Proofs received from author(s): October 21, 1997 